\title{
Review \\ Clinical and Forensic Aspects of the Different Subtypes of Argyria
}

\author{
Luís Mota ${ }^{1, *(\mathbb{D})}$ and Ricardo Jorge Dinis-Oliveira $1,2,3, * \mathbb{D}$ \\ 1 Department of Public Health and Forensic Sciences, and Medical Education, Faculty of Medicine, \\ University of Porto, 4200-319 Porto, Portugal \\ 2 IINFACTS-Institute of Research and Advanced Training in Health Sciences and Technologies, \\ Department of Sciences, University Institute of Health Sciences (IUCS), \\ Advanced Polytechnic and University Cooperative (CESPU), CRL, 4585-116 Gandra, Portugal \\ 3 UCIBIO-REQUIMTE-Applied Molecular Biosciences Unit, Laboratory of Toxicology, \\ Department of Biological Sciences, Faculty of Pharmacy, University of Porto, 4050-313 Porto, Portugal \\ * Correspondence: up201504401@med.up.pt (L.M.); ricardinis@sapo.pt or ricardinis@med.up.pt (R.J.D.-O.); \\ Tel.: +351-224-157-216 (R.J.D.-O.)
}

check for

updates

Citation: Mota, L.; Dinis-Oliveira, R.J. Clinical and Forensic Aspects of the Different Subtypes of Argyria. J. Clin. Med. 2021, 10, 2086. https:// doi.org/10.3390/jcm10102086

Academic Editor: Masutaka Furue

Received: 29 March 2021

Accepted: 11 May 2021

Published: 13 May 2021

Publisher's Note: MDPI stays neutral with regard to jurisdictional claims in published maps and institutional affiliations.

Copyright: (c) 2021 by the authors. Licensee MDPI, Basel, Switzerland. This article is an open access article distributed under the terms and conditions of the Creative Commons Attribution (CC BY) license (https:/ / creativecommons.org/licenses/by/ $4.0 /)$.

\begin{abstract}
Argyria encompasses the different cosmetic alterations that can develop if enough silver particles deposit in a specific tissue, typically in the skin, ranging from localized dark-blue macules to a generalized slate-gray/bluish tinge following systemic absorption. This work aims to fully review the state of the art regarding pathophysiology, diagnosis, treatment, and relevant clinical and forensic features of argyria. Argyria has been diagnosed in a wide range of ages, both sexes and varied ethnicities, with no known individual predisposing factors. Ultraviolet radiation with subsequence increases of melanin production aggravates the discoloration due to a reduction in the silver deposits. Physical examination and silver exposure in the anamnesis can be highly suggestive of the diagnosis, but a histopathological analysis with Energy-Dispersive X-ray Spectroscopy is required to unequivocally determine the discoloration etiology. Safe and effective treatment has only been accomplished with laser techniques, though only a few cases have been reported and with limited follow-up time. In conclusion, argyria typically has an occupational or iatrogenic etiology. It should be suspected when a patient presents with typical skin or eye lesions. A seemingly viable treatment modality, with laser technology, is finally within the horizon.
\end{abstract}

Keywords: argyria; pathophysiology; signs and symptoms; clinical and forensic diagnosis; treatment

\section{Introduction}

Argyria refers to inert silver deposition in a tissue, typically the skin, resulting in characteristic blue/gray spots or a diffuse hue, but also possibly darker or brownish [1-6]. It occurs following excessive accidental voluntary cumulative silver exposure by the most varied causes. It is mainly a cosmetic condition whose clinical presentation will vary according to the subtype as describe below [2,3,7-9].

The state of the art concerning pathophysiology, clinical presentation, diagnosis, therapeutic modalities, and forensic features of argyria is reviewed, and the main gaps in current knowledge, where future research ought to be focused, are highlighted.

\section{Materials and Methods}

An exhaustive search was carried out in PubMed database without a limiting period concerning pathophysiology, signs and symptoms, history and physical examination, diagnostic, treatment, and forensic aspects of argyria. The keyword "argyria" was searched in articles written in all languages. Additionally, the keyword was crossed with diagnosis, toxicokinetics, amalgam tattoo, ocular argyrosis, azure lunula, and treatment. Furthermore, retrieved journal articles, as well as books and governmental documents, were also reviewed for possible additional publications related to this topic. A total of 290 scientific 
documents, including books, articles, and government documents, were considered for this review.

\section{Chemistry and History of Silver}

Silver derives from the Anglo-Saxon "seofor" and "siolfur", and it is a chemical element, solid at room temperature, classified as a transition metal (atomic number 47), of period 5 and group 11 of the Periodic Table. Its symbol is Ag, which derives from its Latin name argentum $[10,11]$. It is a rare, naturally occurring element found as a soft, "silver"-colored metal in its pure form, but in the environment, it is mostly found in its typical oxidation state $(+1)$ combined with other ions or molecules, such as sulfide, chloride, and nitrate, which give the compound a color ranging from dark-gray/black to powdery white $[11,12]$. Of all known metals, silver has the highest electrical and thermal conductivity and possesses the lowest contact resistance [11].

Silver value has been recognized since ancient times, as it was likely separated from lead as early as 4000 BC [10]. Silver metal is used for jewelry, silverware, electronic equipment, and dental filling. Soluble inorganic silver salts (e.g., silver nitrate and silver sulfide) are strongly bactericidal, and particularly silver nitrate $(1 \%)$ had been used immediately after born to prevent gonococcal ophthalmitis in newborns. Antibiotic ointments have replaced silver nitrate for this indication. Silver sulfadiazine slowly releases silver and is used to suppress bacterial growth in patients with second- and third-degree burns wounds. Nevertheless, silver medicinal value is often overemphasized, and unsubstantiated claims for treating diverse diseases are widely reported. Occupational exposure occurs mainly from inhalation of silver fumes and dust in different settings; for instance, silver halide is used in the manufacture of photographic plates [13,14].

There is no essentiality for silver, and dietary intake is in the range of 0.4 to $27 \mu \mathrm{g} / \mathrm{day}$, which is much less than the silver intake from medicinal uses [15]. For drinking water disinfection, World Health Organization permissible level is reported to be $0.1 \mathrm{mg} \mathrm{Ag} / \mathrm{L}$ [16]. One of the recent applications of silver is in nanoparticles (AgNP), materials with sizes ranging from 1 to $100 \mathrm{~nm}$, containing 20 to 15,000 atoms of silver. Because of their antimicrobial activity, AgNP are used in a variety of consumer products, including medical devices, disinfectants, appliances, textiles, and water treatment $[15,17]$.

\section{Toxicokinetics of Silver}

Silver is primarily absorbed by the gastrointestinal tract, lung, and skin $[15,16,18]$. Up to $10 \%$ of ingested silver, a value expected to vary with individual characteristics (at least age, health, and nutritional status) and the degree of ionization/solubility of the silver compound, is absorbed in the gastrointestinal tract [3,13,19-22]. Metallic silver and insoluble silver compounds are not readily absorbed and pose a minimal health risk, unlike particulate or colloidal silver, whose toxicity comes from released ionic particles [13,15]. Inhalation of aerosolized particles, typically occurring in the occupational setting, is also a relevant pathway for silver absorption, but the toxicokinetic properties of this process remain even more uncharacterized [21,23-26]. There has been some consensus around $0.01 \mathrm{mg} / \mathrm{m}^{3}$ as the threshold limit value for daily silver occupational exposure, but a lower limit of $0.1 \mathrm{mg} / \mathrm{m}^{3}$ for metallic silver is becoming more common, as it shows less propensity to cause argyria than its ionic, more soluble and absorbable counterpart [27].

Silver is transported in the bloodstream as a colloid, in its ionic form $\left(\mathrm{Ag}^{+}\right)$, stabilized by complexing with proteins, mainly albumin but also globulins $[20,24,28,29]$. It is widely distributed to most tissues, such as muscle, cerebellum, spleen, duodenum, heart, lung, liver, and kidney [15]. It is not clear whether silver crosses the blood-brain barrier, although several studies indicate accumulation in specific areas of the brain [15]. Indeed, silver deposition has been documented in the blood-brain barrier (vascular endothelium and astrocytes), the blood-cerebrospinal fluid barrier (choroid plexus), and the cerebrospinal fluid itself [30-32]. Moreover, Landas et al. [33] reported a postmortem evaluation with silver deposition in circumventricular organs and hypothalamic nuclei, suggesting silver's 
eventual passage to the central nervous system. Nevertheless, the state of the art is far from being clarified.

The primary routes of exposure for AgNP include excretion occurring predominantly in the bile but also through the urinary system in a much lesser amount [3,19,20,28,34-36]. Indeed, biliary excretion is important in the homeostasis of several metals, notably copper, manganese, cadmium, selenium, gold, silver, and arsenic [37].

\section{Argyria Subtypes}

Silver deposition has been documented in several anatomic places such as the skin, eyes, kidneys, and liver, but it might happen in virtually every organ, which is coherent with silver's general affinity for stromal tissue and basement membranes and, as in the skin, this deposition has not been definitely associated with any harmful effects [20,38-43]. In the following sections, different types of argyria are reviewed.

\subsection{Generalized Argyria}

Generalized argyria (GA; Figure 1) emerges following silver systemic exposure and its uptake by the dermis $[3,5,8,24,44,45]$. This leads to a gray/blue saltish or metallic diffuse skin pigmentation, which becomes evident predominantly in sun-exposed areas $[3,5,38,44,46-48]$. Patients were most commonly present with gradually aggravating face and neck discoloration with a history of oral but also occupational aerosolized exposure to silver-containing products [3,13,28,44,49-54]. Different minimal amounts of elemental silver cumulative oral intake able to produce GA have been suggested, ranging from 2 to $30 \mathrm{~g}$, but such values provide incomplete information unpaired with a time window $[8,19,29,39,55-57]$.

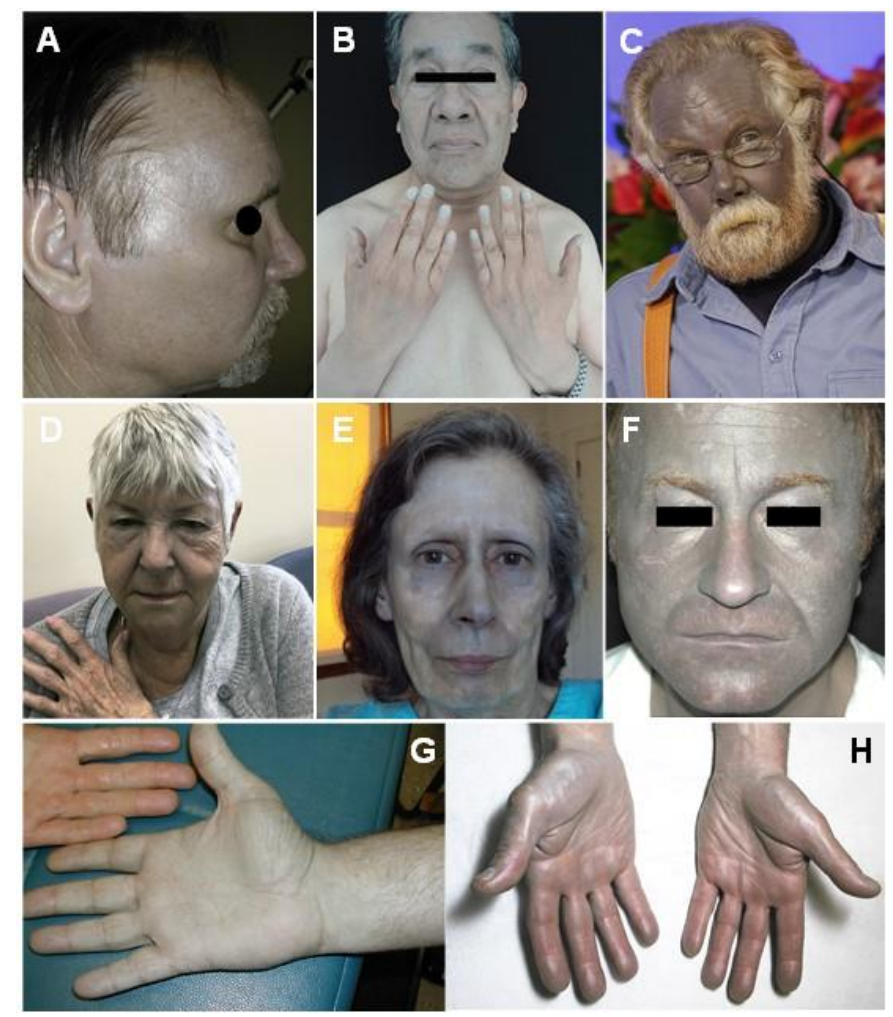

Figure 1. Characteristic bluish-grayish signs of generalized argyria, namely in sun-exposed areas of the head, neck, and hands. Reprinted from (A,G) - [20], (B) - [58], (C)—(Today media news), (D) — [34], (E)—[59], (F)—[47] and (H)—[60].

Azure lunula is a bluish discoloration of the fingernails, more precisely of the lunula (Figure 2), but with the possible extent to the proximal half of the fingernail that was 
frequently accompanying GA $[6,36,47,50,61,62]$. Another possible early sign of GA is acquired pigmentation of the oral mucosa; unlike amalgam tattoos, a diffuse gray/blue tinge will be seen $[1,6,7,49,58,63-66]$.

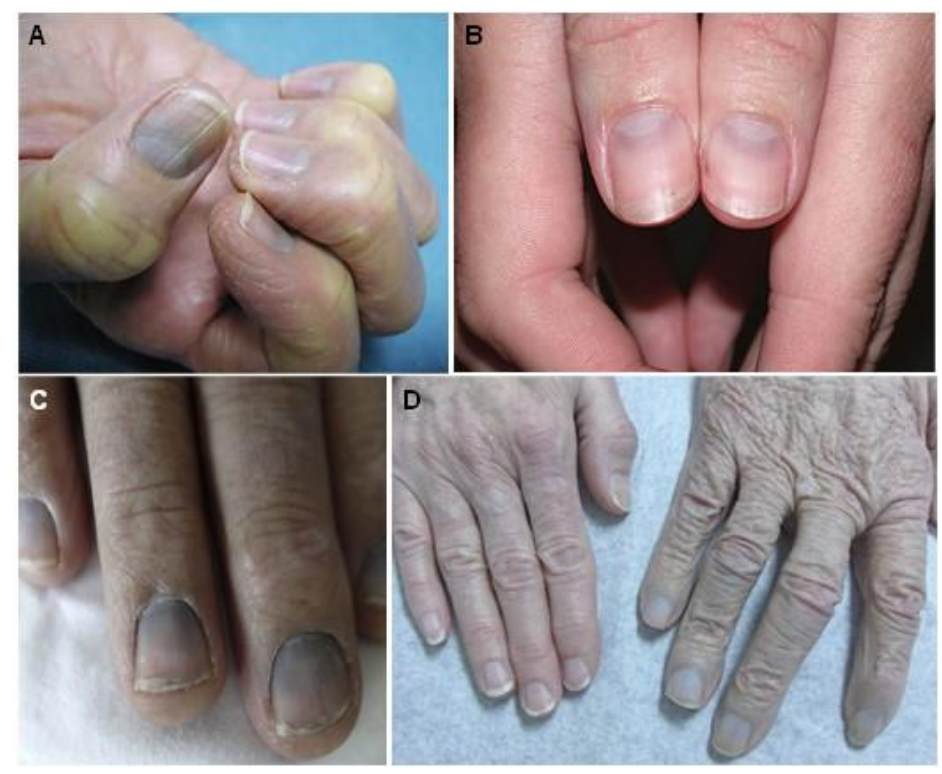

Figure 2. Characteristic bluish-gray discoloration of the nails (azure lunula), namely of the lunula due to silver exposure. In D comparison with regular nails is provided. Reprinted from (A) - [67], (B) - [68], (C)—[66], and (D)—[69].

\subsection{Localized Argyria}

Localized argyria (LA; Figure 3) is less commonly seen, being caused by local silver deposition following skin incisions or percutaneous absorption via sweat gland pores $[3,8,28,70-80]$. This results in macular lesions or spots-clusters, confined to where the silver impregnation occurred and with coherent morphology, whose color, compared to GA's, tends to be darker, sometimes almost black [8,73,81-83]. Patients most commonly present with complaints of asymptomatic lesions in a site of previous trauma, cautery with silver devices, or prolonged contact with silver-containing objects, creams, or solutions, as it occurs in the hands and forearms of silver-handling workers $[2,75,81,82,84-87]$.

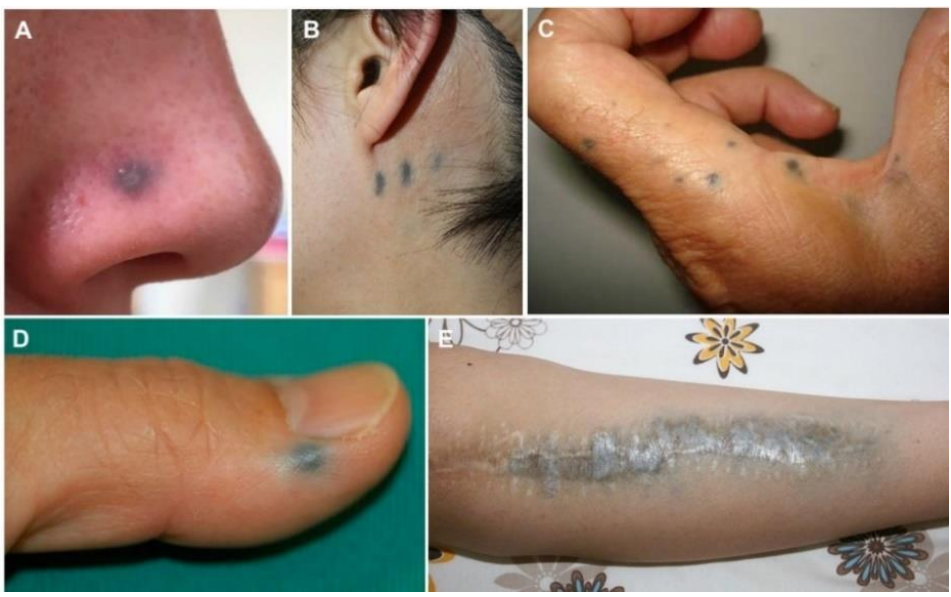

Figure 3. Characteristic dark-bluish-grayish macules of localized argyria following a silver jewelry nose piercing (A), acupuncture treatment (B), silver jewelry in the index finger (C), and maculemimicking a nevus (D). Discoloration of the leg over a silver-coated megaprosthesis used for distal femoral osteosarcoma (E). Reprinted from (A) — [88], (B) — [89], (C)—[87], (D) — [73] and (E)— [90]. 
Amalgam tattoo (Figure 4) is probably the most common form of LA [91-93]. It is is a common and easily recognizable entity that results from the impregnation of silver-contained dental amalgam into oral mucosa following tooth restoration procedures [92,94-98]. A flat, dark-blue mucosal lesion near a restored tooth is highly indicative of an amalgam tattoo, with size varying from small, millimetric lesions to larger ones, with a minority of these even exhibiting radiopacity and potentially triggering a foreign body reaction [92,95]. Besides silver, it is important to highlight that dental amalgams could also present silver, tin, copper, and zinc, which may also have a role in the development of amalgam tattoos [99]. A biopsy might be useful, especially to rule out melanoma $[92,95,96,100]$. Other less common forms of LA reported are in the nasal [101,102], tracheal and bronchial mucosa [103], urinary tract [104-107], vagina [108], and penis [109].
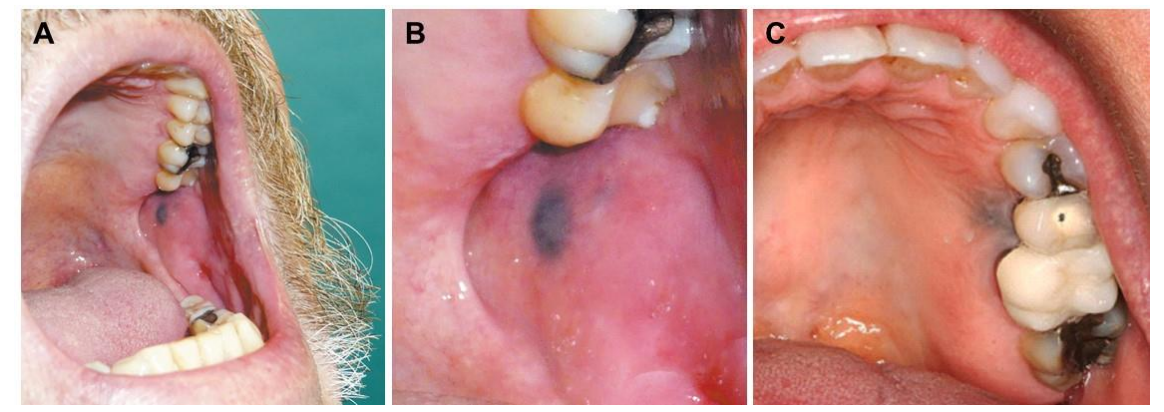

Figure 4. Amalgam tattoo characterized by the dark-blue macule on the buccal mucosa near a restored tooth. Reprinted from $(\mathbf{A}, \mathbf{B})-[95],(\mathbf{C})-[110]$.

\subsection{Argyrosis}

Argyrosis is a particular argyric manifestation evidenced by the ocular silver deposition (Figure 5) that can occur in GA [6,34,47,49,54,111,112], but also as a LA form [113-116]. It is mostly detected in the cornea, bulbar and palpebral conjunctivae, and lacrimal caruncle [113,114,117-120]. Its appearance ranges from small, darker lesions to a more disperse tinge, somewhat parallelly to LA and GA, and with greater heterogeneity concerning coloration, as greenish and brownish tones might be displayed other than the typical gray/blue [121,122].
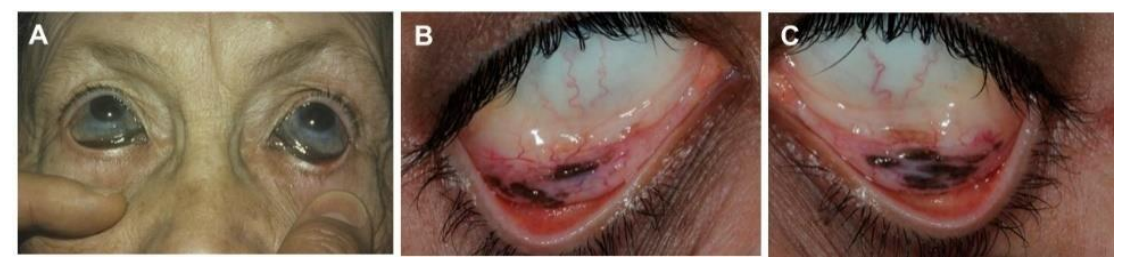

Figure 5. Ocular argyrosis characterized by intense dark pigmentation of the palpebral conjunctiva, with a more discrete bluish hue of the bulbar conjunctive (A) and of the palpebral conjunctiva (B,C), mimicking a conjunctival melanoma. Reprinted from (A) - [123], (B,C)—[119].

\section{Pathophysiology of Argyria}

Covalent adduct formation is common with electrophilic compounds because they react with nucleophilic atoms in proteins and nucleic acids. In general, soft electrophiles prefer to react with soft nucleophiles (low charge-to-radius ratio in both), whereas strong electrophiles react more readily with strong nucleophiles (high charge-to-radius ratio in both), such as the oxygen in nucleic acids. Metal ions as silver and mercury are soft electrophiles that react covalently with soft nucleophiles, particularly thiol groups, such as cysteineabundant collagen fibers and proteoglycans in the extracellular matrix [3,29], and metallothioneins intracellularly, whose synthesis is induced after cellular silver intake [24,30,77,124].

Discoloration develops following ultraviolet exposure since silver ions undergo photoreduction to atomic silver, which can be oxidized mainly to low-solubility and chemically 
stable compounds such as silver sulfide $\left(\mathrm{Ag}_{2} \mathrm{~S}\right)$ and silver selenide $\left(\mathrm{Ag}_{2} \mathrm{Se}\right)[13,29,125-128]$. This photoreduction process is equivalent to the darkening of photographic film following light exposure and leads to argyria and explains its greater notoriety in sun-exposed areas $[9,19,79,129,130]$. In the absence of light as occurs in the gastrointestinal tract, argyric discoloration may be due to the role of tissue enzymes or other redox systems in the conversion of silver to its elemental form $[40,112,130,131]$. The subsequent formation of very low-solubility complexes can be compared to photographic toning/metal tarnishing, as it increases the stability of the silver aggregates and influences the color of the acquired pigmentation, and it also restraints even further silver's interaction potential with biological structures, providing some explanation to its lack of toxicological effects and foreign body reaction generation $[9,98,127,128]$.

There is evidence of silver found intracellularly, lying in the cytoplasm or bound to lysosome-like structures inside histiocytes and fibroblasts, suggesting a cellular uptake role in its cleanup, but not in any way near an extent that enables pigmentation resolution; therefore, silver is clearly found mainly in extracellular locations [3,29,80,81,128,132-136].

After silver gains access to the dermis or other tissues, either carried by the bloodstream (leading to GA) or localized (leading to LA), it deposits in a predictable pattern, as shown by histopathological and ultrastructural studies $[51,70,76,81,85,137]$. Typically, the silver particles settle in the connective tissue underlying epithelial surfaces, arranged in rows of granules, with a propensity for the basement membranes of blood vessels, eccrine sweat glands, and other dermal adnexa, but also depositing along dermal elastic fibers and the dermo-epidermal junction, while staying clear of the epidermis $[4,7,55,64,73,79,81,85,133,134,138-141]$. Of note, the outermost skin layer also influences the macroscopical appearance of the discoloration; since it reflects light in the violet/blue spectrum more than in longer wavelengths, argyria colors are usually perceived as blue/gray at clinical evaluation. In anatomic places where stratum corneum is thicker, color may be less intense; indeed, argyric patients' hands, palms appear less pigmented than the dorsa, despite having a similar concentration of silver particles in the dermal tissue $[45,71,77,79,142-145]$.

Also playing a role in skin darkening is silver's stimulatory effect on melanin production, which appears to be one of the few direct effects of silver particles in surrounding tissues, possibly via an increment on tyrosinase enzyme activity [9,77,78,84,125,146,147].

Regarding azure lunula, the pathophysiology explaining the prevalence of discoloration in the lunula in comparison to nail beds is not yet clarified. What is known is that the nail plate is translucent, allowing the visualization of the underlying nail bed. It also grows thicker distally, being thinner in the lunula. With nail formation, cells move forward from the lunula (keratogenous zone), suffering fragmentation until they are predominantly anucleated, eosinophilic, and arranged in very compact sheets [148]. These two factors (nail plate thickness variation and changes in keratinocytes along the nail plate) might play a role in the color disposition found in argyric nails (azure lunula), as well as a richer vascularization toward the nail matrix when compared to the nail midbed [148].

In the eye, silver deposits exhibit a clear predilection for corneal Descemet's membrane, but it can also be found in Bowman's membrane, the stromal tissue in-between, both bulbar and palpebral conjunctiva and the lacrimal caruncle [25,58,102,113,149-152]. When the lacrimal sac is visualized (following dacryocystectomy), it often displays the pigmentation as well and in a striking fashion, with a strong black tone [114,153,154]. Reports of crystalline lens silver deposits have also been made $[54,114,149,155]$. In the posterior segment of the eye, silver accumulation is speculated about, following reports of retinal pigment epithelium changes, drusenoid deposits, and dark choroids in fluorescein angiogram, but a necessary causal relationship was not yet clearly established [111,156-158]. Following local contact, silver episcleral and periocular inoculation, such as in the eyelids, can also be present $[23,86,159-161]$. Silver's histopathological pattern of deposition will also be similar whether there's local implantation or systemic absorption, behaving as seen elsewhere in the body: settling in epithelial basement membranes and subepithelial 
connective tissue, predominantly extracellularly, and undergoing redox reactions that aggravate the pigmentation and stabilize the silver compounds [102,112]. Following systemic exposure, ocular argyrosis, more specifically corneal and/or conjunctival involvement, is seemingly the earliest indicator of silver accumulation in the body, with its deposition in these tissues being often documented before any other clinical signs of argyria [120,162]. Some authors have even claimed that there is a correlation between the number of eye deposits/degree of coloration and the length of silver exposure [122,163].

\section{Diagnosis of Argyria}

Argyria is often overlooked as a differential diagnosis of pigmented lesions, given its rarity $[8,45,83,164]$. Any of these findings might correspond to argyria: a slate-gray/bluish change of the complexion in sun-exposed areas, localized dark-blue lesions, eye gray/brown/dark spots or conjunctival pigmentation, or the characteristic nail changes seen in azure lunula $[34,46,48,61,73,82,115,165]$. Silver product exposition, as in oral silver consumption in a GA-suitable patient, a previous dental restoration in a patient presenting with amalgam tattoos, or acupuncture history in a patient with dispersing cutaneous LA lesions, can be highly indicative of argyria $[5,53,86,89]$. Different causes have been documented, and Table 1 compiles all major causes of argyria.

Table 1. Overview of major causes of argyria.

\begin{tabular}{|c|c|c|}
\hline Treatment & Cause & References \\
\hline $\begin{array}{l}\text { Gastrointestinal conditions (ingestion of } \\
\text { silver-containing colloids/pills) }\end{array}$ & Iatrogenic, systemic & {$[135,166-174]$} \\
\hline $\begin{array}{l}\text { Leukoplakia patch (topical application of } \\
\text { silver nitrate) }\end{array}$ & Iatrogenic, topical & [175] \\
\hline $\begin{array}{l}\text { Epilepsy and other neuropsychiatric conditions } \\
\text { (ingestion of silver-containing pills) }\end{array}$ & Iatrogenic, systemic & {$[40,131,176,177]$} \\
\hline Alopecia (ingestion of silver-containing colloids) & Iatrogenic, systemic & [52] \\
\hline $\begin{array}{l}\text { Prophylaxis of gonococcal ophthalmia neonatorum } \\
\text { (application of silver nitrate collyrium) }\end{array}$ & Iatrogenic, topical & {$[46,105,178]$} \\
\hline Syphilis (topical application of silver arsphenamine) & Iatrogenic, topical & {$[126,131]$} \\
\hline $\begin{array}{l}\text { Wounds/ulcers/burns (topical application of silver } \\
\text { sulfadiazine cream for asepsis, silver nitrate for } \\
\text { chemical cautery/hemostasis, and/or use of } \\
\text { silver-impregnated suture threads/surgical clips) }\end{array}$ & $\begin{array}{l}\text { Iatrogenic, topical and/or } \\
\text { systemic (if bloodstream } \\
\text { is reached) }\end{array}$ & {$[70,84,85,105,128,141,179-187]$} \\
\hline $\begin{array}{c}\text { Strabismus surgery (application of silver nitrate } \\
\text { collyrium and/or use of silver-impregnated suture } \\
\text { threads/surgical clips) }\end{array}$ & Iatrogenic, topical & {$[160,161,188]$} \\
\hline $\begin{array}{c}\text { Trachoma (topical application of silver nitrate for } \\
\text { chemical cautery) }\end{array}$ & Iatrogenic, topical & [121] \\
\hline $\begin{array}{c}\text { Conjunctivitis/eye soreness/epiphora (application } \\
\text { of silver-containing collyrium) }\end{array}$ & Iatrogenic, topical & {$[114,153,154,189,190]$} \\
\hline $\begin{array}{l}\text { Pharyngitis/throat soreness (topical throat } \\
\text { application of pulverized silver and/or ingestion of } \\
\text { silver-containing tablets) }\end{array}$ & $\begin{array}{l}\text { Iatrogenic, topical (pharyngeal) } \\
\text { and/or systemic }\end{array}$ & {$[67,144,191-194]$} \\
\hline $\begin{array}{l}\text { Hematuria (instillation of the urinary tract with } \\
\text { silver nitrate preparations) }\end{array}$ & Iatrogenic, topical & [105-107] \\
\hline
\end{tabular}


Table 1. Cont.

\begin{tabular}{|c|c|c|}
\hline Treatment & Cause & References \\
\hline $\begin{array}{c}\text { Smoking cessation (chewing/ingestion of } \\
\text { silver-coated sugar particles and/or silver acetate } \\
\text { lozenges/pills) }\end{array}$ & Iatrogenic, systemic & {$[57,126,195-198]$} \\
\hline $\begin{array}{l}\text { Varicose veins (injection of silver nitrate as } \\
\text { sclerosant) }\end{array}$ & $\begin{array}{l}\text { Iatrogenic, topical, and/or } \\
\text { systemic }\end{array}$ & [130] \\
\hline $\begin{array}{l}\text { Intractable diplopia (use of silver nitrate-coated } \\
\text { soft lenses) }\end{array}$ & Iatrogenic, topical & [199] \\
\hline $\begin{array}{l}\text { Antiseptic and astringent properties (application of } \\
\text { silver-containing vasoconstricting nose drops) }\end{array}$ & $\begin{array}{l}\text { Iatrogenic, topical, and/or } \\
\text { systemic (silver is drained } \\
\text { posteriorly and ingested) }\end{array}$ & {$[5,40,47,55,59,64,126,134,186,200-205]$} \\
\hline $\begin{array}{l}\text { Dental restoration (silver-containing filling material } \\
\text { for endodontic procedures) }\end{array}$ & Iatrogenic, topical & {$[92-94,96-98,100,185,206-209]$} \\
\hline Halitosis (silver-containing breath-freshening pills) & Non-medical, systemic & {$[8,210]$} \\
\hline $\begin{array}{l}\text { Belief in general health benefits/immune system } \\
\text { boosting/alternative medicine (ingestion of } \\
\text { silver-containing colloids, application of } \\
\text { silver-containing nasal drops) }\end{array}$ & $\begin{array}{l}\text { Non-conventional medicine, } \\
\text { systemic }\end{array}$ & $\begin{array}{c}{[1,6,9,20,22,34,38,44,45,49-} \\
51,58,62,66,68,69,125,211-228]\end{array}$ \\
\hline $\begin{array}{l}\text { Skin-breaching trauma with } \\
\text { silver-containing material }\end{array}$ & Accidental, topical & {$[145,229]$} \\
\hline $\begin{array}{l}\text { Antibiotic properties (use of silver-coated } \\
\text { prosthetic implants) }\end{array}$ & $\begin{array}{l}\text { Iatrogenic, topical, and/or } \\
\text { systemic (if bloodstream is } \\
\text { reached) }\end{array}$ & {$[90,230]$} \\
\hline Photochemical industry & $\begin{array}{l}\text { Occupational, topical (skin, eye, } \\
\text { and intranasal deposition), } \\
\text { and/or systemic (inhalation) }\end{array}$ & {$[112,152,231]$} \\
\hline $\begin{array}{l}\text { Occupational silver manipulation, silver } \\
\text { soldering/silversmithing in jewelry/art crafting }\end{array}$ & $\begin{array}{l}\text { Occupational, topical (skin and } \\
\text { eye) and/or systemic (inhalation) }\end{array}$ & {$[54,77,80,119,122,150,163,232-234]$} \\
\hline Eyelash tinting & Non-medical, topical & {$[115,235]$} \\
\hline Acupuncture & $\begin{array}{l}\text { Non-conventional medicine, } \\
\text { topical }\end{array}$ & {$[8,89,98,139,140,236-241]$} \\
\hline Silver earrings/piercings & Non-medical, topical & {$[2,71,72,74,88,137,138,165,242,243]$} \\
\hline $\begin{array}{l}\text { Silver-coated nuts and/or spices (areca and betel } \\
\text { nut) }\end{array}$ & $\begin{array}{l}\text { Non-medical, systemic (oral } \\
\text { intake) }\end{array}$ & {$[7,91]$} \\
\hline
\end{tabular}

The timespan for the onset of the pigmentation might vary from days to several years, and it then becomes ever lasting, making the diagnosis of argyria not discardable regardless of the amount of time passed since exposition and first-time pigmentation observation $[8,81,83,87,134,164,165,188,222,244]$. These should prompt a thorough anamnesis to ascertain if there is any kind of pathological or toxicological justification for these alterations and to establish a differential diagnosis (Table 2). 
Table 2. Differential diagnosis for other argyria-mimicking pigmentations of skin and other tissues. GA, generalized argyria;

LA, localized argyria.

\begin{tabular}{|c|c|c|}
\hline Pathological Condition of Xenobiotic & Description & References \\
\hline Hemochromatosis & $\begin{array}{c}\text { Generalized skin } \\
\text { hyperpigmentation (GA) }\end{array}$ & {$[40,56,64,69,126,134,167,178,245-247]$} \\
\hline Lead poisoning & $\begin{array}{c}\text { Blue line along the gingival margins at } \\
\text { the base of the teeth } \\
\text { (LA/amalgam tattoo) }\end{array}$ & {$[5,7,40,91]$} \\
\hline Methemoglobinemia/sulfhemoglobinemia & $\begin{array}{l}\text { Generalized skin brownish-blue to gray } \\
\text { pigmentation (as in cyanosis) (GA) }\end{array}$ & {$[4,40,56,126,134,141,178,245,246,248]$} \\
\hline Toxic melanodermatitis & Hyperpigmented skin lesions (LA, GA) & [132] \\
\hline Minocycline & $\begin{array}{l}\text { Blue staining of teeth or blue-gray skin } \\
\text { lesions (GA) }\end{array}$ & {$[7,64,132,249]$} \\
\hline Chlorpromazine/Phenothiazines & $\begin{array}{l}\text { Slate gray-bluish skin discoloration in } \\
\text { sun-exposed areas (GA) }\end{array}$ & {$[64,132,178,250]$} \\
\hline Amiodarone & $\begin{array}{l}\text { Slate gray-bluish skin discoloration in } \\
\text { sun-exposed areas (GA) }\end{array}$ & {$[7,64,125,251]$} \\
\hline Antimalarial agents & $\begin{array}{l}\text { Blue-gray discolorations of the mouth } \\
\text { and skin (LA, GA) }\end{array}$ & {$[55,79,132,246]$} \\
\hline Clofazimine & $\begin{array}{l}\text { Grayish skin plaques or generalized gray } \\
\text { skin pigmentation (LA, GA) }\end{array}$ & {$[7,132]$} \\
\hline Cyanosis/cyanotic heart disease & $\begin{array}{l}\text { Generalized skin brownish-blue to gray } \\
\text { pigmentation (GA) }\end{array}$ & $\begin{array}{c}{[1,8,20,36,40,43,45,53,56,66,69,131,169} \\
178,200,245,246,248,252-256]\end{array}$ \\
\hline Nevus & Flat or raised pigmented skin lesion (LA) & {$[2,71,73,76,82,133,137,164,229,241]$} \\
\hline End-stage renal disease/uremia & Heterogenous skin lesions (LA, GA) & [36] \\
\hline $\begin{array}{c}\text { Melanoma of the } \\
\text { skin/conjunctiva/oral mucosa }\end{array}$ & $\begin{array}{l}\text { Pigmented lesion, usually asymmetric, } \\
\text { with heterogenous color and } \\
\text { time-evolving (LA/amalgam tattoo) }\end{array}$ & $\begin{array}{c}{[23,82,92,95,96,100,101,119,133,159,178} \\
188,240,246,257]\end{array}$ \\
\hline Chrysiasis & $\begin{array}{l}\text { Slate-gray to blue skin pigmentation, } \\
\text { especially in sun-exposed areas, nail } \\
\text { pigmentation (LA, GA, azure lunula) }\end{array}$ & {$[36,64,79,113,178,237,246,258]$} \\
\hline Iron salts & Brown to red skin lesions (LA) & [79] \\
\hline Ochronosis & Bluish-black skin lesions (LA, GA) & {$[64,76,113,259,260]$} \\
\hline Wilson's disease & $\begin{array}{l}\text { Generalized skin hyperpigmentation, } \\
\text { Kayser-Fleischer rings (GA, OA) }\end{array}$ & {$[55,113]$} \\
\hline Tobacco (chewing) & $\begin{array}{l}\text { Brownish-black staining of the oral } \\
\text { mucosa (LA/amalgam tattoo) }\end{array}$ & \multirow{5}{*}{ [91] } \\
\hline Chlorophyll (mouthwash) & $\begin{array}{l}\text { Blackening of the tongue } \\
\text { (LA/amalgam tattoo) }\end{array}$ & \\
\hline Sodium perborate (mouthwash) & $\begin{array}{l}\text { Blackening of the tongue } \\
\text { (LA/amalgam tattoo) }\end{array}$ & \\
\hline Ariboflavinosis & $\begin{array}{l}\text { Diffuse bluish-purple discoloration of the } \\
\text { buccal mucosa (GA) }\end{array}$ & \\
\hline Peutz-Jeghers syndrome & $\begin{array}{c}\text { Dark blue-brown hyperpigmented } \\
\text { gingival macules (LA/amalgam tattoo) }\end{array}$ & \\
\hline Addison's disease & $\begin{array}{l}\text { Generalized bronze-like skin } \\
\text { pigmentation, diffuse pigmentation of } \\
\text { gingiva, tongue, and buccal mucosa (GA) }\end{array}$ & {$[53,58,69,91,134,178,214,245]$} \\
\hline
\end{tabular}


Table 2. Cont.

\begin{tabular}{ccc}
\hline Pathological Condition of Xenobiotic & Description & References \\
\hline Bismuthosis & $\begin{array}{c}\text { Blue-black, sharply limited pigmentation } \\
\text { of marginal gingivae, nail pigmentation } \\
\text { (LA/amalgam tattoo, GA, azure lunula) }\end{array}$ & {$[36,79,91,134,178,246]$} \\
Mercurialism & $\begin{array}{c}\text { Diffuse blue-gray to black gingival } \\
\text { pigmentation, nail pigmentation } \\
\text { (LA/amalgam tattoo, azure lunula) }\end{array}$ & {$[36,79,91,140,178]$} \\
\hline Arseniasis & $\begin{array}{c}\text { Generalized skin hyperpigmentation } \\
\text { with hyperkeratosis (GA) }\end{array}$ & {$[5,7,79,91]$} \\
\hline Accidental tattoo & Dark-blue/black macules/patterns (LA) & {$[133]$} \\
\hline
\end{tabular}

\subsection{Signs and Symptoms Related to Argyria}

Signs and symptoms derived from silver exposure other than the cosmetic changes are usually absent, even after systemic absorption, suggesting that silver has low toxicity in humans $[3,6,9,13,58,131,132,147,261]$. The silver deposits in the skin do not seem to cause any harm to the surrounding tissues, being the psychosocial embarrassment derived from the aesthetic impact usually the most negative consequence, sometimes even leading to social withdrawal $[9,43,47,55,132,223]$.

Patients with OA have reported visual symptoms, most commonly nyctalopia [54], and presented with concomitant comorbidities, such as glaucoma [151,163], cataract $[114,149,218,262]$, diabetic retinopathy [111], as well as posterior eye segment changes somewhat coherent with the functional complaints $[157,158]$, but without direct link to the silver deposition itself $[156,162,263]$. This inconsistency, alongside several OA patients lacking any visual complaints, has contributed to some consensus regarding the seemingly innocuous silver deposition in the eye, though this claim still needs a more robust foundation $[21,113,261,263,264]$.

As silver has been found to settle in several tissues, concern has been raised regarding possible systemic toxic effects. Regarding the kidney, a decrease in the glomerular filtration rate has been suggested, after reports of nephrotic syndrome [265], membranous nephropathy [266], and acute or chronic renal failure [22,181,267] following argyria, but a causal relationship could not be indisputably defined. Still, it should be highlighted that the development of an antineutrophil cytoplasmic antibodies (ANCA) negative pauciimmune glomerulonephritis in a 47-year-old woman with a T-cell lymphoma has been reported, suggesting that the silver deposition in glomerular basement membranes, though seemingly innocuous, might be the trigger for leucocyte-mediated aggression in patients with a background of auto-immunity disorders [268].

Liver toxicity following silver deposition has also been suggested but, apart from transient hepatic enzyme elevation with no clinical significance, no evidence of pathological liver processes caused by silver accumulation has been found [5,55,182,223,269]. Indeed, most argyric patients, as well as individuals exposed to silver without clinical signs of argyria, present with corresponding laboratory parameters within reference values for healthy people $[6,48,49,51,52,66,69,132,144,211,212,218,230,263]$. Argyric patients might require special attention when radiotherapy is required after a report of a radiation dermatitis possibly explained/aggravated by the dermal silver deposition [215].

Lung fibrosis in silver finishers has also been reported [270,271]. Even though silver's contribution to said outcome remains speculative, the inhalation of silver dust cannot be ruled out as a causative factor for pneumoconiosis.

It has also been considered that silver exposition might precipitate neurological and/or psychiatric events. There have been reports of argyric patients presenting with diverse neurological clinical pictures, ranging from acute seizures to neurodegenerative disorders or even peripheral neuropathy $[32,128,183,195,217,222,272]$, but the potential causal relationship remains inconclusive as the cases reported are rare and do not allow extrapo- 
lation. Regarding argyria affecting psychiatric patients, the possible causal relationship seems to be the opposite, as delusional beliefs often are what leads to unmeasured silver consumption $[195,211,214,224,273]$.

\subsection{Medical Exams}

To better characterize the suspected pigmentation and exclude the differential diagnosis, histopathological analysis of the affected tissue is particularly important [7]. After conventional tissue section processing and staining with hematoxylin and eosin, the dark deposits may be seen both in bright and dark field microscopy, with the latter being more sensitive as they appear refractile, arranged as described above in the pathophysiology section $[7,55,84,87,133,139,213]$. Ultrastructural analysis of skin biopsies, but also of the kidney and choroid plexus, allows visualization of electron-dense particles, typically round or ovoid in shape but sometimes more irregular, and with a greater axis ranging from 10 to 1000 nanometers $[31,80,127,132,133,140]$. Reflectance confocal microscopy has also been used, namely for LA work-up, as it can help quickly excluding melanocytic proliferation [133].

To establish an unequivocal diagnosis, an Energy-Dispersive X-ray Spectroscopy (EDXS) must be undertaken as this technique, whose apparatus is generally attached to electron microscopes, allows identification of the chemical elements found in the granules via analysis of their emitted energy spectrum, making it the gold-standard tool for argyria definite diagnosis $[38,39,83,84,132,133,141,164]$. While being non-invasive, it presents remarkable specificity and sensitivity (estimated limit of detection of 3 to $4 \mathrm{ppm}$ ) for silver, as well as for other chemical elements such as selenium and sulfur, and it might even allow monitoring of subclinical silver deposition in occupationally exposed workers $[133,164,274]$. Other documented auxiliary diagnostic methods are the neutron activating analysis, which allows determination of the silver content in the skin, hair, urine samples, or the whole body, but the advantages it can bring being routinely used in the clinical setting are scarce $[126,275,276]$. With resort to atomic absorption spectrometry and, more recently, inductively coupled plasma mass spectrometry [230], measurement of serum and urinary silver levels [9,54], as well as in feces, hair [28,35,263], kidney and liver wet tissue samples [180], might help to determine the body burden of silver, but these parameters have shown to be consistently reliable neither for risk assessment of argyria development nor for diagnosis of the condition $[9,28,35,54,180,230,263]$.

Dermatoscopy is also often employed, particularly in the evaluation of LA, typically exhibiting a dark, dense, and homogenous pigmentation [82,83,87,89,133]. Enei et al. [71] showed that dermatoscopy might allow a peek into some detail of the histopathological pattern: dermal papillary silver seemingly appears as dots, perieccrine pigment as circumferences/ellipses, and the silver along the interpapillary dermis as linear structures. While it cannot diagnose argyria, it may provide helpful information in excluding differential diagnosis [65].

Slit-lamp biomicroscopy is the first step in the diagnostic approach of OA, revealing a particulate pattern in the cornea, but this technique, possibly complemented with confocal microscopy, should be employed for exposure monitoring, or if GA is suspected even without clinical evidence of OA, since cornea's Descemet's membrane displays silver deposits quite early following either systemic or local exposition, making slit-lamp examination a sensitive index for both GA and OA [102,117,118,120,157,162,199]. Other ophthalmological tests have also been reported, such as fluorescein angiography, optical coherence tomography, and electroretinogram, but their purpose so far has been mainly to find eye structural and functional changes related to argyria rather than establishing the diagnosis and with extrapolations limited due to the number and type of studies $[149,156-158,218,222]$.

\section{Treatment}

Spontaneous argyria regression or any kind of intermittence cannot be expected, as the silver remains inert in the deposition sites indefinitely; in order words, the pigmentation 
is permanent without treatment $[4,13,19,47,56,131,166]$. At this point, the degree of sun exposition will determine the discoloration aggravation, with cessation of silver exposure being critical to avoid worsening of the aesthetical alteration, but seemingly futile in what concerns reverting it $[5,34,39,178,223,225]$. Therefore, the use of cosmetics can help to mask the discoloration, and sunscreens might be beneficial in preventing further pigmentation when sun exposure is unavoidable $[7,36]$. At the occupational level, periodic slit-lamp biomicroscopy and monitoring of silver aerial concentration have been suggested to ensure the employees' safety [120,162,261]. Contrasting with these general findings, Wu et al. [121] reported a case of presumed $\mathrm{OA}$ following silver nitrate cautery of the palpebral conjunctiva with clinical and confocal microscopy regression with a follow-up of three years.

\subsection{Treatment of Argyria}

For a long time, there has not been an effective and safe treatment method for argyria $[13,19,26,36,135,141]$. Numerous approaches to remove the coloration are reported in the literature, but none with appreciable success: depigmenting creams, chelation therapy with different drugs such as 2,3-dimercapto-1-propanol (i.e., dimercaprol), 2,3-dimercapto1-propanesulfonic acid (DMPS), sodium thiosulfate, potassium ferrocyanide, potassium iodide, ethylenediaminetetraacetic acid (EDTA), methenamine and D-penicillamine/ $\mathrm{N}$-acetyl-DL-penicillamine, hydroquinone and dermal abrasion all proved ineffective in removing silver deposits from the body [26,55,62,127,141,192,200,276-279]. Some of these chelating agents have been reported to lighten the pigmentation in small skin areas after intradermal injection, particularly sodium thiosulfate and potassium ferrocyanide, but results are inconsistent, and their application to larger areas would be quite incommodious and burdensome, with the risks associated far outweighing the unlikely benefits $[19,55,131,178,245]$.

In the last few years, cases of successful skin pigmentation resolution with conventional tattoo-removal laser techniques have been reported, offering insight in a promising treatment modality that might revolutionize argyria's natural disease progression and the psychological burden. Both Q-Switched 1064 nanometers Neodymium-doped Yttrium Aluminum Garnet Laser (Q-S $1064 \mathrm{~nm}$ Nd:YAG laser) and Q-Switched Picosecond 755 nanometers Alexandrite Laser (Q-S P $755 \mathrm{~nm}$ Alexandrite Laser) have been reported to yield satisfactory results. The former, ranging from a fluence of 0.7 to $8 \mathrm{~J} / \mathrm{cm}^{2}$, a pulse duration of 5 to $50 \mathrm{~ns}$, a frequency of 5 to $10 \mathrm{~Hz}$, and a spot size of 2 to $8 \mathrm{~mm}[139,219,223,252,280,281]$, produced immediate results, restoring the expected skin coloration for each subject in the targeted areas $[51,63,142,282]$. As with the latter, at least similar efficacy was obtained within reported values of 0.71 to $2.83 \mathrm{~J} / \mathrm{cm}^{2}$ regarding fluence, $0.75 \mathrm{~ns}$ regarding pulse duration, 3 to $5.5 \mathrm{~mm}$ regarding spot size, and $10 \mathrm{~Hz}$ regarding frequency $[74,216,219,220]$. The persistence of restored skin coloration has been reported up to one year after treatment $[142,223,252,282]$. Otherwise, there has been one report of argyria pigmentation recurrence 11 months after Q-S $1064 \mathrm{~nm}$ Nd:YAG laser treatment, despite the patient stating discontinuation of silver exposure, use of facial and body sunscreen with a sun protection factor superior or equal to 30 , and resort to physical sun-protective barriers $[63,283]$. Figure 6 evidence the effect of the treatment with Q-S $1064 \mathrm{~nm}$ Nd:YAG laser.

Both procedures provoke very intense pain [280], seemingly greater as fluence increases and more area is to be depigmented [282]. For this reason, technicians have resorted to varied anesthesia techniques, with general anesthesia being offered in some cases $[51,142]$. Beyond that and a transient inflammation of the skin with edema, erythema, and scaling $[74,88]$, no other significant adverse effects or sequelae have been reported, with adequate healing of the treated areas [51,142,216,219,223,252,281,282]. 

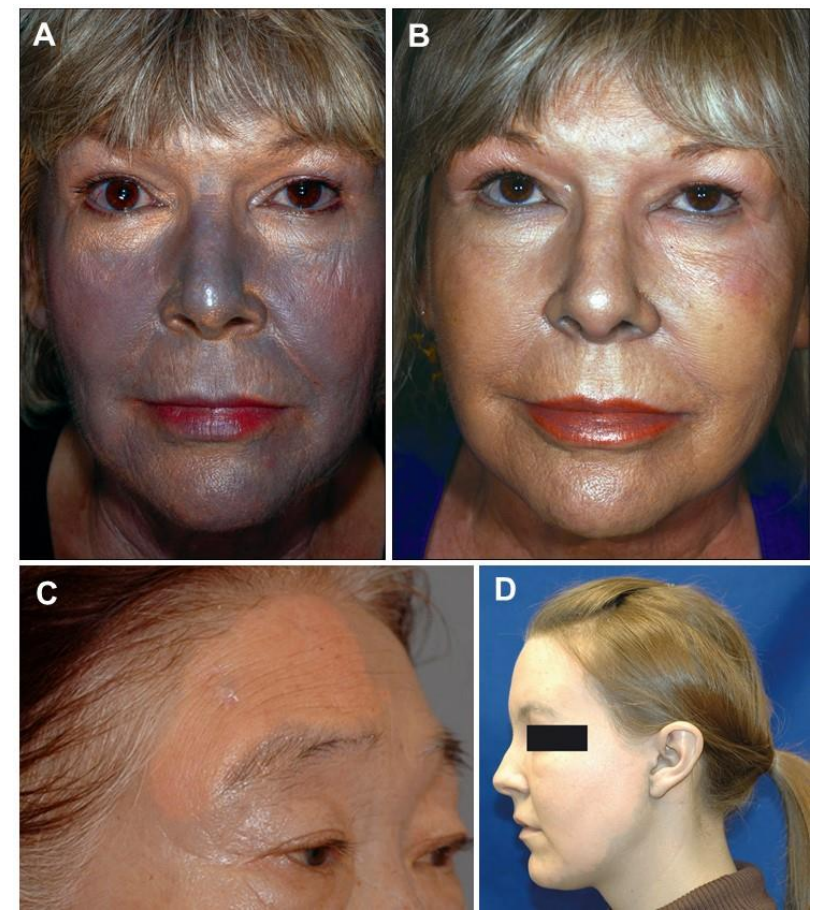

Figure 6. Laser treatment of argyria of the face and neck before and after a single pass of a Q-S $1064 \mathrm{~nm}$ Nd:YAG laser (A,B), notorious discoloration lightening of the right half of the forehead (C), and visible contrast between untreated (neck) and treated (face) areas (D). Reprinted from $(\mathbf{A}, \mathbf{B})-[63],(\mathbf{C})-[252]$ and (D) - [282].

The precise mechanism behind the disappearance of the pigmentation is not totally clear. It was initially postulated that the silver particles, once laser-targeted, would fragment, with their remnants being phagocytosed and removed from the skin via lymphatic uptake in a similar fashion to what occurs with conventional tattoos; this hypothesis is consistent with the decrease in the number of silver granules observed by light microscopy of post-treatment biopsies [223,252]. However, this mechanism would not be able to explain the macroscopical whitening of the skin obtained right after laser appliance, nor the fact that immediate post-treatment biopsies, taken from normal-appearing skin, revealed persistence of silver particles, which suggests laser treatment affects silver particles' plasmon resonance, altering its emitted optical spectrum and allowing skin color restoration despite silver persistence [282,283]. It was speculated that Q-S $1064 \mathrm{~nm}$ Nd:YAG treatment might reverse the intradermal photoactivated reaction that silver particles go through after sunlight exposure, but their persistence in the skin allows argyria relapse if ultraviolet radiation reaccumulates [283]. Shao et al. [220] recently reported that after Q-S P $755 \mathrm{~nm}$ Alexandrite Laser, the silver particles, previously large enough to be seen by light microscopy with hematoxylin and eosin staining, were no longer able to be visualized by this means. Electron microscopy showed that the silver had not been removed from the skin but rather remained in similar locations, only now fragmented; particles went from approximately 25-100 nanometers to 4-15 nanometers, arranged in clusters. Two months after treatment with Q-S $1064 \mathrm{~nm}$ Nd:YAG laser, the persistence of perieccrine silver in macroscopically normal-appearing skin areas, documented with scanning electron microscopy, has been reported [282]. These data, along with Mock et al. [284] findings that heat treatment can modify silver nanoparticles' geometrical shape, altering their emitted light spectrum wavelength, help put together the most robust explanation so far as to why clinical argyria provisional resolution, at least, can be obtained despite silver persistence in the skin and emphasizes the need not discard the possibility of argyria relapse even with silver exposure discontinuation. 


\subsection{Treatment of Amalgam Tattoo}

The treatment of amalgam tattoos has also been an object of attention. The operator should irrigate the intervened area thoroughly to ensure all traces of silver-containing root canal sealer are properly cleaned up and removed to prevent the lesion onset, especially when the procedure requires soft tissue flap reflection [96]. After LA develops, if the lesion is cosmetically unacceptable, surgical excision and transplantation of oral mucosal tissue/free gingival grafting, as well as subepithelial connective tissue grafts, have been reported, with heterogenous results (even with LA resolution, the final aesthetic outcome might not be optimal) $[92,206,207,285]$. Regarding secondary prevention, periradicular surgery to remove the amalgam restorations and reduce the amount of dispersed silver particles before grafting the affected tissue has been reported [206].

\subsection{Treatment of Argyrosis}

Following acute angle-closure glaucoma, the use of Q-S Nd:YAG laser iridotomy in a patient with ocular argyrosis was reported, with each laser shot causing clearance of the argyrotic deposits anterior to the iridotomy site; the procedure was also performed in the contralateral eye as a preventive measure [151]. The cleared cornea areas remained unchanged for at least eight months, the follow-up period.

\section{Forensic and Toxicological Aspects}

Scarce postmortem evaluations of argyric patients have been reported [31-33,40,42,135]. A substantiated link between silver exposure and death was not found, with the patients often having many comorbidities or a clear non-related cause of death [21,31-33,40,42,135]. Still, these contributed to strengthening the notion that silver deposition can happen in several organs without leading to any clinically perceived consequences $[31,33,40,42,135]$. Autopsy findings after silver treatment of burn victims indicate the highest levels occur in the skin, gingiva, cornea, liver, and kidneys [15].

Silver and silver nanoparticles are relatively nontoxic, supporting their wide application $[15,16,18,286]$. Lesions of the kidneys and lungs and arteriosclerosis have been attributed to both industrial and medicinal exposures [15]. Deposition of silver in renal glomerular basement membranes after high-level exposure may produce hypertension and possible cardiac complications $[15,287]$. At lower exposure levels, more subtle effects of impaired endothelial function and inhibition of vascular endothelial growth factor action result in impaired angiogenesis and vasorelaxation $[287,288]$. The respiratory tract may be affected in severe cases of silver intoxication. Chronic bronchitis has also been reported to result from the medicinal use of colloidal silver. Large oral doses of silver nitrate or acetate may cause severe gastrointestinal irritation due to its caustic action [18]. After ingestion of $15 \mathrm{~mL}$ of silver nitrate solution, excruciating burning pain in the throat and nostrils was reported, but with the absence of any other symptoms or signs other than a whitish membrane on the oral mucosa, even after upper gastrointestinal endoscopy [289]. It has been reported that levels of AgNP administered i.v. at a dose above $20 \mathrm{mg} / \mathrm{kg}$ are toxic [290]. Silver has very limited genotoxic effects and is not considered a carcinogen.

\section{Conclusions and Future Perspectives}

A precise cut point for silver ingested after which GA development should be expected has not been determined, for which contributes to the rarity of this occurrence but also the unawareness of argyric patients regarding the silver products' composition and their consumption magnitude [64,200,211,220,221].

Argyria is the staining of tissues following silver accumulation [1,2,4]. It can be categorized as GA or LA, whether silver reaches the afflicted tissue(s) via the systemic bloodstream or local impregnation, respectively [44,70,72]. Furthermore, LA can be classified according to the site of deposition, with the most notorious types being cutaneous localized argyria, ocular argyrosis, and amalgam tattoos [2,97,112]. General major characteristics of argyria are resumed in Figure 7. 


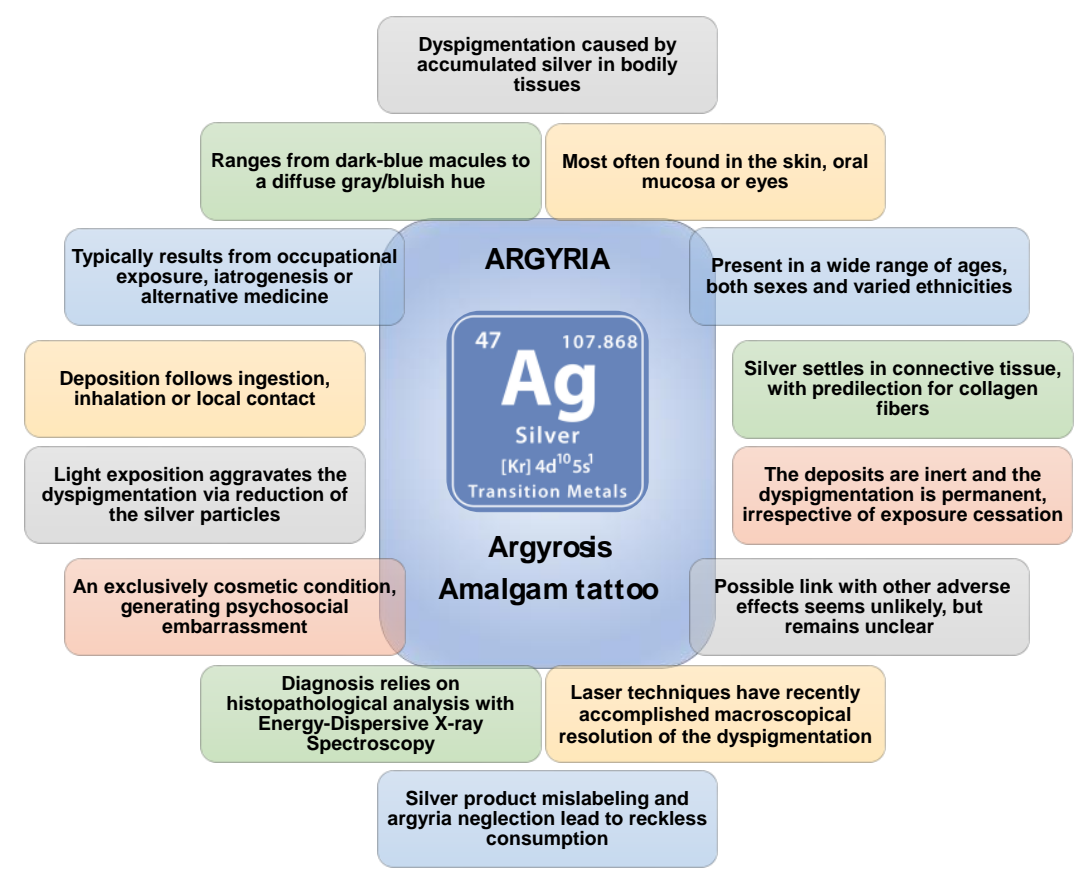

Figure 7. Major characteristics of different forms of argyria.

In the genesis of argyria development, several silver sources have been identified, which can be divided into three main categories: iatrogenic, occupational, and alternative medicine-related (Table 1). Currently, silver compounds in medicine have been refined, and indications for their use are restrained when compared to the past, being mainly related to the local application for asepsis insurance, wound cautery, and teeth restoration, avoiding systemic exposure [8]. Work conditions have also improved, with the advent of adequate ventilation and proper protective equipment, making the onset of argyria following occupational exposure a much rarer event $[8,81]$. These, along with hoodwinking marketing, mainly online, responsible for spreading misinformation about silver health benefits and neglecting its potential hazards, have caused an increase in the number of agyria case reports, particularly generalized argyria, with neither medical nor occupational genesis $[20,66,89,200,244]$. Except for light exposure, which plays an important role in aggravating the pigmentation, other factors besides silver exposition itself, contributing to argyria onset, are not known $[48,79,130]$.

Argyric patients usually present with the absence of signs and symptoms related to argyria. What brings them forth is the aesthetical nuisance, which can lead to significant embarrassment and social withdrawal, even more after realizing that the pigmentation is permanent $[9,132,143,223]$. To diagnose argyria, physical examination and anamnesis alone can be very accurate, but maximum specificity is only achieved with EDXS of the stained tissue, as it allows ascertainment of silver present in the deposits, as well as quantification of other present nanoparticles [73,74,128,144,146].

Novel treatment modalities, with greater safety and effectivity than those ever achieved with previous techniques, now exist. Q-S $1064 \mathrm{~nm}$ Nd:YAG laser and Q-S P $755 \mathrm{~nm}$ Alexandrite Laser have shown potential to diametrically change argyria's prognosis from permanent coloration to the restoration of previous complexion [216,219,223]. Future studies further looking into these techniques can help better clarify the mechanism of pigment resolution, optimize the results, and truly bring renewed hope to argyric patients.

Author Contributions: Conceptualization, R.J.D.-O.; data curation, formal analysis, and writingoriginal draft preparation, L.M.; writing-review and editing, L.M. and R.J.D.-O.; supervision, R.J.D.-O. All authors have read and agreed to the published version of the manuscript. 
Funding: This research received no external funding. The authors have no relevant affiliations or financial involvement with any organization or entity with a financial interest in or financial conflict with the subject matter or materials discussed in the manuscript. This includes employment, consultancies, honoraria, stock ownership or options, expert testimony, grants or patents received or pending, and royalties.

Institutional Review Board Statement: All procedures were performed according to the ethical and legal standards of the institution.

Informed Consent Statement: Not applicable.

Data Availability Statement: Not applicable.

Conflicts of Interest: The authors declare no conflict of interest. No writing assistance was used in the production of this manuscript.

\section{References}

1. Burgert, J.M. Argyria resulting from chronic use of colloidal silver in a patient presenting for colonoscopy. AEA Pract. 2014, 3, 73-75. [CrossRef]

2. Boix-Vilanova, J.; Del Pozo, L.J.; Martinez, M.; Ramos, D.; Izquierdo, N. Dermoscopy of localised argyria: Apropos of five cases. Australas. J. Dermatol. 2020, 61, e122-e123. [CrossRef] [PubMed]

3. Bingham, E.; Cohrssen, B. Patty's Toxicology, 6th ed.; Wiley-Blackwell: Hoboken, NJ, USA, 2012.

4. Witkowski, J.A.; Parish, L.C. On being blue: Argyria still exists. Skinmed 2004, 3, 304-305. [CrossRef] [PubMed]

5. Van de Voorde, K.; Nijsten, T.; Schelfhout, K.; Moorkens, G.; Lambert, J. Long-term use of silver containing nose-drops resulting in systemic argyria. Acta Clin. Belg. 2005, 60, 33-35. [CrossRef]

6. Kim, Y.; Suh, H.S.; Cha, H.J.; Kim, S.H.; Jeong, K.S.; Kim, D.H. A case of generalized argyria after ingestion of colloidal silver solution. Am. J. Ind. Med. 2009, 52, 246-250. [CrossRef]

7. Kubba, A.; Kubba, R.; Batrani, M.; Pal, T. Argyria an unrecognized cause of cutaneous pigmentation in Indian patients: A case series and review of the literature. Indian J. Dermatol. Venereol. Leprol. 2013, 79, 805-811. [CrossRef]

8. Sato, S.; Sueki, H.; Nishijima, A. Two unusual cases of argyria: The application of an improved tissue processing method for X-ray microanalysis of selenium and sulphur in silver-laden granules. Br. J. Dermatol. 1999, 140, 158-163. [CrossRef]

9. White, J.M.; Powell, A.M.; Brady, K.; Russell-Jones, R. Severe generalized argyria secondary to ingestion of colloidal silver protein. Clin. Exp. Dermatol. 2003, 28, 254-256. [CrossRef]

10. Lai-Becker, M.W.; Burns, M.M. Silver. In Goldfrank's Toxicologic Emergencies, 11th ed.; McGraw-Hill Education: New York, NY, USA, 2019.

11. National Center for Biotechnology Information. PubChem Element Summary for Atomic Number 47, Silver; NCBI: Bethesda, MD, USA, 2004.

12. National Center for Biotechnology Information. PubChem Compound Summary for CID 23954, Silver; NCBI: Bethesda, MD, USA, 2004.

13. Drake, P.L.; Hazelwood, K.J. Exposure-related health effects of silver and silver compounds: A review. Ann. Occup. Hyg. 2005, 49, 575-585. [CrossRef]

14. Lee, J.H.; Kwon, M.; Ji, J.H.; Kang, C.S.; Ahn, K.H.; Han, J.H.; Yu, I.J. Exposure assessment of workplaces manufacturing nanosized $\mathrm{TiO}_{2}$ and silver. Inhal. Toxicol. 2011, 23, 226-236. [CrossRef]

15. Hadrup, N.; Lam, H.R. Oral toxicity of silver ions, silver nanoparticles and colloidal silver-A review. Regul. Toxicol. Pharmacol. 2014, 68, 1-7. [CrossRef] [PubMed]

16. World Health Organization. Silver as a Drinking-Water Disinfectant; WHO: Geneva, Switzerland, 2018.

17. Klaassen, C.D. Casarett and Doull's Toxicology: The Basic Science of Poisons, 9th ed.; McGraw-Hill Education: New York, NY, USA, 2019.

18. Wang, Z.; Xia, T.; Liu, S. Mechanisms of nanosilver-induced toxicological effects: More attention should be paid to its sublethal effects. Nanoscale 2015, 7, 7470-7481. [CrossRef] [PubMed]

19. Fung, M.C.; Bowen, D.L. Silver products for medical indications: Risk-benefit assessment. J. Toxicol. Clin. Toxicol. 1996, 34, 119-126. [CrossRef]

20. Wadhera, A.; Fung, M. Systemic argyria associated with ingestion of colloidal silver. Dermatol. Online J. $2005,11,12$.

21. Lansdown, A.B. A pharmacological and toxicological profile of silver as an antimicrobial agent in medical devices. Adv. Pharmacol. Sci. 2010, 2010, 910686. [CrossRef]

22. Mayr, M.; Kim, M.J.; Wanner, D.; Helmut, H.; Schroeder, J.; Mihatsch, M.J. Argyria and decreased kidney function: Are silver compounds toxic to the kidney? Am. J. Kidney Dis. 2009, 53, 890-894. [CrossRef] [PubMed]

23. Palamar, M.; Midilli, R.; Egrilmez, S.; Akalin, T.; Yagci, A. Black tears (melanodacryorrhea) from argyrosis. Arch. Ophthalmol. 2010, 128, 503-505. [CrossRef] [PubMed]

24. Lansdown, A.B. Silver in health care: Antimicrobial effects and safety in use. Curr. Probl. Dermatol. 2006, 33, 17-34. [CrossRef] 
25. Hanna, C.; Fraunfelder, F.T.; Sanchez, J. Ultrastructural study of argyrosis of the cornea and conjunctiva. Arch. Ophthalmol. 1974, 92, 18-22. [CrossRef]

26. Bleehen, S.S.; Gould, D.J.; Harrington, C.I.; Durrant, T.E.; Slater, D.N.; Underwood, J.C. Occupational argyria; light and electron microscopic studies and X-ray microanalysis. Br. J. Dermatol. 1981, 104, 19-26. [CrossRef]

27. Health and Safety Executive. EH40/2005 Workplace Exposure Limits; HSE: London, UK, 2020.

28. Williams, N. Longitudinal medical surveillance showing lack of progression of argyrosis in a silver refiner. Occup. Med. (Lond.) 1999, 49, 397-399. [CrossRef]

29. Jonas, L.; Bloch, C.; Zimmermann, R.; Stadie, V.; Gross, G.E.; Schäd, S.G. Detection of silver sulfide deposits in the skin of patients with argyria after long-term use of silver-containing drugs. Ultrastruct. Pathol. 2007, 31, 379-384. [CrossRef]

30. Lansdown, A.B. Critical observations on the neurotoxicity of silver. Crit. Rev. Toxicol. 2007, 37, 237-250. [CrossRef]

31. Goebel, H.H.; Muller, J. Ultrastructural observations on silver deposition in the choroid plexus of a patient with argyria. Acta Neuropathol. 1973, 26, 247-251. [CrossRef]

32. Mirsattari, S.M.; Hammond, R.R.; Sharpe, M.D.; Leung, F.Y.; Young, G.B. Myoclonic status epilepticus following repeated oral ingestion of colloidal silver. Neurology 2004, 62, 1408-1410. [CrossRef] [PubMed]

33. Landas, S.; Fischer, J.; Wilkin, L.D.; Mitchell, L.D.; Johnson, A.K.; Turner, J.W.; Theriac, M.; Moore, K.C. Demonstration of regional blood-brain barrier permeability in human brain. Neurosci. Lett. 1985, 57, 251-256. [CrossRef]

34. Bracey, N.A.; Zipursky, J.S.; Juurlink, D.N. Argyria caused by chronic ingestion of silver. Can. Med. Assoc. J. 2018, 190, E139. [CrossRef]

35. DiVincenzo, G.D.; Giordano, C.J.; Schriever, L.S. Biologic monitoring of workers exposed to silver. Int. Arch. Occup. Environ. Health 1985, 56, 207-215. [CrossRef]

36. Sue, Y.M.; Lee, J.Y.; Wang, M.C.; Lin, T.K.; Sung, J.M.; Huang, J.J. Generalized argyria in two chronic hemodialysis patients. Am. J. Kidney Dis. 2001, 37, 1048-1051. [CrossRef]

37. Dijkstra, M.; Havinga, R.; Vonk, R.J.; Kuipers, F. Bile secretion of cadmium, silver, zinc and copper in the rat. Involvement of various transport systems. Life Sci. 1996, 59, 1237-1246. [CrossRef]

38. Kwon, H.B.; Lee, J.H.; Lee, S.H.; Lee, A.Y.; Choi, J.S.; Ahn, Y.S. A case of argyria following colloidal silver ingestion. Ann. Dermatol. 2009, 21, 308-310. [CrossRef]

39. Guenova, E.; Schaller, M. Residents' corner September 2012. CarpeDIEM-Dermatological indications for electron microscopy: Argyria. Eur. J. Dermatol. 2012, 22, 718. [CrossRef] [PubMed]

40. Gettler, A.O.; Rhoads, C.P.; Weiss, S. A Contribution to the pathology of generalized argyria with a discussion of the fate of silver in the human body. Am. J. Pathol. 1927, 3, 631-652.

41. Rauber, G.; Duprez, A.; Bibas, H. Argyria with hepatic localization. Apropos of a case. Med. Chir. Dig. 1981, 10, 319-320.

42. Dietl, H.W.; Anzil, A.P.; Mehraein, P. Brain involvement in generalized argyria. Clin. Neuropathol. 1984, 3, 32-36.

43. Prescott, R.J.; Wells, S. Systemic argyria. J. Clin. Pathol. 1994, 47, 556-557. [CrossRef]

44. Brandt, D.; Park, B.; Hoang, M.; Jacobe, H.T. Argyria secondary to ingestion of homemade silver solution. J. Am. Acad. Dermatol. 2005, 53, S105-S107. [CrossRef] [PubMed]

45. Chang, A.L.; Khosravi, V.; Egbert, B. A case of argyria after colloidal silver ingestion. J. Cutan. Pathol. 2006, 33, 809-811. [CrossRef] [PubMed]

46. Pezzarossa, E.; Alinovi, A.; Ferrari, C. Generalized argyria. J. Cutan. Pathol. 1983, 10, 361-363. [CrossRef]

47. Tomi, N.S.; Kränke, B.; Aberer, W. A silver man. Lancet 2004, 363, 532. [CrossRef]

48. Bianchi, L.; Orlandi, A.; Di Stefani, A.; Ricci, R.; Chimenti, S. "Familial” generalized argyria. Arch. Dermatol. 2006, 142, 789-790. [CrossRef]

49. Reddy, S.G.; Martin, J.M.t.; Kraus, E.W.; Meffert, J.J. Generalized blue-gray pigmentation—Quiz case. Arch. Dermatol. 2009, 145, 1053-1058. [CrossRef]

50. Park, S.W.; Shin, H.T.; Lee, K.T.; Lee, D.Y. Medical concern for colloidal silver supplementation: Argyria of the nail and face. Ann. Dermatol. 2013, 25, 111-112. [CrossRef]

51. Butzmann, C.M.; Technau-Hafsi, K.; Bross, F. "Silver man" argyria of the skin after ingestion of a colloidal silver solution. J. Dtsch. Dermatol. Ges. 2015, 13, 1030-1032. [CrossRef]

52. Gülseren, D.; Arzberger, E.; Cerroni, L.; Hofmann-Wellenhof, R.; Richtig, E. Reflectance confocal microscopy and dermatopathologic findings of cutaneous argyria after colloidal silver ingestion. J. Eur. Acad. Dermatol. Venereol. 2017, 31, e178-e179. [CrossRef] [PubMed]

53. Wickless, S.C.; Shwayder, T.A. Medical mystery-The answer. N. Engl. J. Med. 2004, 351, 2349-2350. [CrossRef]

54. Osińska, J.; Poborc-Godlewska, J.; Kieć-Swierczyńska, M.; Głuszcz, M. 6 cases of argyria among workers engaged in silverplating radio subunits. Med. Pr. 1982, 33, 361-364.

55. Pariser, R.J. Generalized argyria. Clinicopathologic features and histochemical studies. Arch. Dermatol. 1978, $114,373-377$. [CrossRef]

56. Plack, W.; Bellizzi, R. Generalized argyria secondary to chewing photographic film. Report of a case. Oral Surg. Oral Med. Oral Pathol. 1980, 49, 504-506. [CrossRef]

57. Hanada, K.; Hashimoto, I.; Kon, A.; Kida, K.; Mita, R. Silver in sugar particles and systemic argyria. Lancet 1998, $351,960$. [CrossRef] 
58. Molina-Hernandez, A.I.; Diaz-Gonzalez, J.M.; Saeb-Lima, M.; Dominguez-Cherit, J. Argyria after Silver Nitrate Intake: Case Report and Brief Review of Literature. Indian J. Dermatol. 2015, 60, 520. [CrossRef]

59. Jacobs, R. Argyria: My life story. Clin. Dermatol. 2006, 24, 66-69. [CrossRef] [PubMed]

60. Baker, J.W.; Leidy, K.L.; Smith, K.M.; Okeke, U.S. Argyria associated with use of systemic colloidal silver. Fed. Pract. 2011, 28, 39-42.

61. Plewig, G.; Lincke, H.; Wolff, H.H. Silver-blue nails. Acta Derm. Venereol. 1977, 57, 413-419.

62. McKenna, J.K.; Hull, C.M.; Zone, J.J. Argyria associated with colloidal silver supplementation. Int. J. Dermatol. $2003,42,549$. [CrossRef] [PubMed]

63. Gottesman, S.P.; Goldberg, G.N. Immediate successful treatment of argyria with a single pass of multiple Q-switched laser wavelengths. JAMA Dermatol. 2013, 149, 623-624. [CrossRef]

64. Lencastre, A.; Lobo, M.; João, A. Argyria-Case report. An. Bras. Dermatol. 2013, 88, 413-416. [CrossRef]

65. Cinotti, E.; Labeille, B.; Douchet, C.; Cambazard, F.; Perrot, J.L. Dermoscopy, reflectance confocal microscopy, and high-definition optical coherence tomography in the diagnosis of generalized argyria. J. Am. Acad. Dermatol. 2017, 76, S66-S68. [CrossRef]

66. Rodriguez, V.; Romaguera, R.L.; Heidecker, B. Silver-Containing Wound Cream Leading to Argyria-Always Ask About Alternative Health Products. Am. J. Med. 2017, 130, e145-e146. [CrossRef]

67. Fox, J.D.; Baker, J.A.; Tosti, A. Chromonychia in an Asymptomatic Vitamin Consumer. Ski. Appendage Disord. 2016, 1, 131-133. [CrossRef]

68. Kalouche, H.; Watson, A.; Routley, D. Blue lunulae: Argyria and hypercopprecaemia. Australas. J. Dermatol. 2007, 48, 182-184. [CrossRef]

69. Merchant, F.; Carpenter, T. Blue-gray discoloration of the skin. Am. Fam. Physician 2011, 84, 821-822.

70. Ellison, D.W.; Chant, A.D.; Harrison, T.A.; Theaker, J.M. Localized argyria: A complication of the repair of inguinal hernia with silver filigree. Br. J. Surg. 1993, 80, 1325. [CrossRef] [PubMed]

71. Enei, M.L.; Paschoal, F.M.; Valdés, R. Argyria mimicking a blue nevis: Dermoscopy features. An. Bras. Dermatol. 2013, 88, 452-455. [CrossRef] [PubMed]

72. Beutler, B.D.; Lee, R.A.; Cohen, P.R. Localized cutaneous argyria: Report of two patients and literature review. Dermatol. Online J. 2016, 22, 11 .

73. Nagano, T.; Oka, M.; Horikawa, T.; Nishigori, C.; Kotera, M. Single, blue nevus-like localized argyria. J. Dermatol. 2016, 43, 1359-1360. [CrossRef] [PubMed]

74. Friedmann, D.P.; Buckley, S.; Mishra, V. Localized cutaneous argyria from a nasal piercing successfully treated with a Picosecond 755-nm Q-Switched Alexandrite Laser. Dermatol. Surg. 2017, 43, 1094-1095. [CrossRef] [PubMed]

75. Isak, V.; Beerli, T.; Cozzio, A.; Flatz, L. A Rare Case of Localized Argyria on the Face. Case Rep. Dermatol. 2019, 11, 23-27. [CrossRef]

76. Robinson-Bostom, L.; Pomerantz, D.; Wilkel, C.; Mader, R.; Lerner, L.; Dufresne, R.; Flotte, T. Localized argyria with pseudoochronosis. J. Am. Acad. Dermatol. 2002, 46, 222-227. [CrossRef]

77. Buckley, W.R. Localized argyria. Arch. Dermatol. 1963, 88, 531-539. [CrossRef]

78. Buckley, W.R.; Oster, C.F.; Fassett, D.W. Localized argyria, II. Chemical nature of the silver containing particles. Arch. Dermatol. 1965, 92, 697-705. [CrossRef] [PubMed]

79. Granstein, R.D.; Sober, A.J. Drug and heavy metal-induced hyperpigmentation. J. Am. Acad. Dermatol. 1981, 5, 1-18. [CrossRef]

80. Rongioletti, F.; Robert, E.; Buffa, P.; Bertagno, R.; Rebora, A. Blue nevi-like dotted occupational argyria. J. Am. Acad. Dermatol. 1992, 27, 1015-1016. [CrossRef]

81. Kapur, N.; Landon, G.; Yu, R.C. Localized argyria in an antique restorer. Br. J. Dermatol. 2001, 144, 191-192. [CrossRef] [PubMed]

82. Sendagorta, E.; Herranz, P.; Casado, B.; Gómez, C.; Ramírez, P.; Feito, M.; García-Cabezas, M.A. Scattered blue maculae in a patient with albinism. Clin. Exp. Dermatol. 2011, 36, 419-420. [CrossRef]

83. Kwon, I.H.; Ahn, H.H.; Ryu, H.J.; Rhyu, I.J. Sudden appearance of black macules on palmar aspect of two university chemistry students. Int. J. Dermatol. 2016, 55, e167-e169. [CrossRef]

84. Fisher, N.M.; Marsh, E.; Lazova, R. Scar-localized argyria secondary to silver sulfadiazine cream. J. Am. Acad. Dermatol. 2003, 49, 730-732. [CrossRef]

85. Schwieger-Briel, A.; Kiritsi, D.; Schumann, H.; Meiss, F.; Technau, K.; Bruckner-Tuderman, L. Grey spots in a patient with dystrophic epidermolysis bullosa. Br. J. Dermatol. 2010, 163, 1124-1126. [CrossRef]

86. Rumayor Piña, A.; Martínez Martínez, M.; Toral Rizo, V.H.; Ajudarte Lopes, M.; Paes de Almeida, O. Cutaneous amalgam tattoo in a dental professional: An unreported occupational argyria. Br. J. Dermatol. 2012, 167, 1184-1185. [CrossRef]

87. Garcias-Ladaria, J.; Hernandez-Bel, P.; Torregrosa-Calatayud, J.L.; Martínez-Aparicio, A. Localized cutaneous argyria: A report of 2 cases. Actas Dermo. Sifiliogr. 2013, 104, 253-254. [CrossRef]

88. Al-Niaimi, F. Localized argyria from silver nasal piercing unresponsive to Q-switched laser successfully treated with a 1064 picoseconds laser. J. Cosmet. Dermatol. 2020, 19, 1535-1536. [CrossRef]

89. Park, M.Y.; Lee, J.S.; Jin, H.J.; You, H.S.; Kim, G.W.; Ko, H.C.; Kim, B.S.; Kim, M.B.; Kim, H.S. Localized argyria: Troublesome side-effect of acupuncture. J. Eur. Acad. Dermatol. Venereol. JEADV 2018, 32, e62-e65. [CrossRef]

90. Karakasli, A.; Hapa, O.; Akdeniz, O.; Havitcioğlu, H. Dermal argyria: Cutaneous manifestation of a megaprosthesis for distal femoral osteosarcoma. Indian J. Orthop. 2014, 48, 326-328. [CrossRef] [PubMed] 
91. Dummett, C.O. Systemic significance of oral pigmentation and discoloration. Postgrad. Med. 1971, 49, 78-82. [CrossRef] [PubMed]

92. Buchner, A. Amalgam tattoo (amalgam pigmentation) of the oral mucosa: Clinical manifestations, diagnosis and treatment. Refuat Hapeh Vehashinayim (1993) 2004, 21, 25-28.

93. Wu, Q.; Yang, Z.; Su, L. Light microscope and energy dispersive X-ray analysis of amalgam pigmentation. Zhonghua Kou Qiang Yi Xue Za Zhi 1995, 30, 140-142. [PubMed]

94. Bell, C.D.; Cooksey, D.E.; Nickel, W.R. Amalgam tattoo (localized argyria). Arch. Derm. 1952, 66, 523-525. [CrossRef]

95. Dubach, P.; Caversaccio, M. Images in clinical medicine. Amalgam tattoo. N. Engl. J. Med. 2011, 364, e29. [CrossRef]

96. Kirchoff, D.A. Localized argyria after a surgical endodontic procedure. Report of a case. Oral Surg. Oral Med. Oral Pathol. 1971, 32, 613-617. [CrossRef]

97. Kehoe, J.C. Intracanal corrosion of a silver cone producing a localized argyria: Scanning electron microscope and energy dispersive X-ray analyzer analyses. J. Endod. 1984, 10, 199-201. [CrossRef]

98. Matsumura, T.; Kumakiri, M.; Ohkawara, A.; Himeno, H.; Numata, T.; Adachi, R. Detection of selenium in generalized and localized argyria: Report of four cases with X-ray microanalysis. J. Dermatol. 1992, 19, 87-93. [CrossRef] [PubMed]

99. Weathers, D.R.; Fine, R.M. Amalgam tattoo of oral mucosa. Arch. Dermatol. 1974, 110, 727-728. [CrossRef] [PubMed]

100. Aoyagi, H.; Katagiri, M. Long-term effects of Ag-containing alloys on mucous tissue present in biopsy samples. Dent. Mater. J. 2004, 23, 340-347. [CrossRef] [PubMed]

101. Ferrara, G.; Filosa, A.; Mariani, M.P.; Fasanella, L. Occupational Argyria of the Nasal Mucosa. Head Neck Pathol. 2018, 12, $252-254$. [CrossRef] [PubMed]

102. Güemes-Villahoz, N.; Burgos-Blasco, B.; CasoViesca, A.; Benitez-Del-Castillo, J.M. Non invasive methods to diagnose ocular argyrosis. J. Fr. Ophtalmol. 2020, 43, e185-e187. [CrossRef] [PubMed]

103. Secretan, J.P.; Demontmollin, D. Several cases of industrial argyrosis of the rhino-bronchial mucous membranes. Pract. Otorhinolaryngol. (Basel) 1965, 27, 167-171.

104. Liakhovitskiü, N.S. Argyria of the urethra. Urol. Nefrol. (Mosk.) 1968, 33, 59-61.

105. Gordon, D.H.; Singla, S.K.; Goode, R.; Pollack, H.M.; Glanz, S. Argyrosis of the urinary tract. Am. J. Roentgenol. 1981, 136, 423-426. [CrossRef]

106. Matzinger, M.A.; Gray, R.R.; Leekam, R.N.; Grosman, H.; St Louis, E.L. Argyrosis of the urinary tract. J. Clin. Ultrasound 1985, 13, 288-290. [CrossRef]

107. Kojima, Y.; Uchida, K.; Takiuchi, H.; Wakatsuki, A.; Sakurai, T.; Fujita, Y.; Shirai, D.; Kobayashi, Y. Argyrosis of the urinary tract after silver nitrate instillation: Report of a case. Hinyokika Kiyo 1993, 39, 41-44.

108. Thomas, K.; Sproston, A.R.; Kingsland, C.R. A case of vaginal argyrosis: All that glistens isn't gold. BJOG Int. J. Obstet. Gynaecol. 2001, 108, 890-891. [CrossRef] [PubMed]

109. Griffiths, M.R.; Milne, J.T.; Porter, W.M. Penile argyria. Br. J. Dermatol. 2006, 155, 1074-1075. [CrossRef] [PubMed]

110. Hall, B.J.; Cockerell, C.J.; Chisholm, C.; Vandergriff, T.; Jessup, C.; Motaparthi, K.; Elston, D.M. Amalgam Tattoo. In Diagnostic Pathology: Nonneoplastic Dermatopathology, 2nd ed.; Elsevier: Amsterdam, The Netherlands, 2017.

111. Madi, H.A.; Steel, D.H.W.; Kotagiri, A.K. Multimodal imaging in a patient with ocular argyrosis complicated by diabetic retinopathy. Can. J. Ophthalmol. 2018, 53, e262-e266. [CrossRef]

112. Jensen, S.F. Argyrosis of conjunctiva in studio photographer. Acta Ophthalmol. (Copenh.) 1962, 40, 544-547. [CrossRef]

113. Hodson, T.J.; Gillies, W.E. Argyrol, argyrosis and the acquisition of art. Aust. N. Z. J. Ophthalmol. 1985, 13, 391-394. [CrossRef] [PubMed]

114. Couto, A., Jr.; Molles, S.; Simionato, R.; Kamlot, D. Eye's and excretory lacrimal apparatus' argyrosis: Case report. Arq. Bras. Oftalmol. 2009, 72, 836-838. [CrossRef] [PubMed]

115. Weiler, H.H.; Lemp, M.A.; Zeavin, B.H.; Suarez, A.F. Argyria of the cornea due to self-administration of eyelash dye. Ann. Ophthalmol. 1982, 14, 822-823. [PubMed]

116. Karcioglu, Z.A.; Caldwell, D.R. Corneal argyrosis: Histologic, ultrastructural and microanalytic study. Can. J. Ophthalmol. 1985, 20, 257-260. [PubMed]

117. Pala, G.; Fronterré, A.; Scafa, F.; Scelsi, M.; Ceccuzzi, R.; Gentile, E.; Candura, S.M. Ocular argyrosis in a silver craftsman. J. Occup . Health 2008, 50, 521-524. [CrossRef]

118. Sánchez-Pulgarín, M.; Matilla, M.; Martinez-de-la-Casa, J.M.; Jerez, M.; Benítez-del-Castillo, J.M. Confocal microscopy in ocular argyrosis. Cornea 2010, 29, 580-582. [CrossRef] [PubMed]

119. Tendler, I.; Pulitzer, M.P.; Roggli, V.; Abramson, D.H.; Marr, B.P. Ocular argyrosis mimicking conjunctival melanoma. Cornea 2017, 36, 747-748. [CrossRef] [PubMed]

120. Gutman, F.A.; Crosswell, H.H., Jr. Argyrosis of the cornea without clinical conjunctival involvement. Am. J. Ophthalmol. 1968, 65, 183-187. [CrossRef]

121. Wu, M.; Wang, X.; Shao, T.; Wang, Y. Case Report: In vivo confocal microscopic appearance of corneal argyrosis. Optom. Vis. Sci. 2017, 94, 1066-1069. [CrossRef] [PubMed]

122. Scroggs, M.W.; Lewis, J.S.; Proia, A.D. Corneal argyrosis associated with silver soldering. Cornea 1992, 11, 264-269. [CrossRef] [PubMed]

123. Texas Tech University Health Sciences Center. List Eye Atlas Contributors. SOM Ophthalmology Eye Atlas: Conjunctiva. 2021. Available online: https://www.ttuhsc.edu/medicine/ophthalmology/eye-atlas/conjunctiva.aspx (accessed on 12 April 2021). 
124. Leite, C.M.; Botelho, A.S.; Oliveira, J.R.; Cardoso, S.V.; Loyola, A.M.; Gomez, R.S.; Vaz, R.R. Immunolocalization of HLA-DR and metallothionein on amalgam tattoos. Braz. Dent. J. 2004, 15, 99-103. [CrossRef] [PubMed]

125. Amber, K.T.; Winslow, C.Y.; Styperek, A.; Schwartz, P.H.; Shiman, M.I.; Elgart, G. Blue skin. Int. J. Dermatol. 2014, 53, 275-276. [CrossRef] [PubMed]

126. East, B.W.; Boddy, K.; Williams, E.D.; Macintyre, D.; McLay, A.L. Silver retention, total body silver and tissue silver concentrations in argyria associated with exposure to an anti-smoking remedy containing silver acetate. Clin. Exp. Dermatol. 1980, 5, 305-311. [CrossRef]

127. Aaseth, J.; Olsen, A.; Halse, J.; Hovig, T. Argyria-tissue deposition of silver as selenide. Scand. J. Clin. Lab. Investig. 1981, 41, 247-251. [CrossRef]

128. Westhofen, M.; Schäfer, H. Generalized argyrosis in man: Neurotological, ultrastructural and X-ray microanalytical findings. Arch. Otorhinolaryngol. 1986, 243, 260-264. [CrossRef]

129. Peterson, W.C., Jr. Argyria. Minn. Med. 1968, 51, 533-534.

130. Shelley, W.B.; Shelley, E.D.; Burmeister, V. Argyria: The intradermal "photograph", a manifestation of passive photosensitivity. J. Am. Acad. Dermatol. 1987, 16, 211-217. [CrossRef]

131. Marshall, J.P., 2nd; Schneider, R.P. Systemic argyria secondary to topical silver nitrate. Arch. Dermatol. 1977, 113, 1077-1079. [CrossRef] [PubMed]

132. Massi, D.; Santucci, M. Human generalized argyria: A submicroscopic and X-ray spectroscopic study. Ultrastruct. Pathol. 1998, 22, 47-53. [CrossRef] [PubMed]

133. García-Martínez, P.; López Aventín, D.; Segura, S.; Gómez-Martín, I.; Lloreta, J.; Ibáñez, J.; Elvira, J.J.; Pujol, R.M. In vivo reflectance confocal microscopy characterization of silver deposits in localized cutaneous argyria. Br. J. Dermatol. 2016, 175, 1052-1055. [CrossRef]

134. Rich, L.L.; Epinette, W.W.; Nasser, W.K. Argyria presenting as cyanotic heart disease. Am. J. Cardiol. 1972, 30, 290-292. [CrossRef]

135. Steininger, H.; Langer, E.; Stömmer, P. Generalized argyrosis. Dtsch. Med. Wochenschr. 1990, 115, 657-662. [CrossRef]

136. Reymond, J.L.; Stoebner, P.; Amblard, P. Cutaneous argyria: An electron microscopic study of four eases with microanalysis X study of one case (author's transl). Ann. Dermatol. Venereol. 1980, 107, 251-255.

137. Shall, L.; Stevens, A.; Millard, L.G. An unusual case of acquired localized argyria. Br. J. Dermatol. 1990, 123, 403-407. [CrossRef]

138. Wootton, C.I.; May, T.; Khan, M.; Walker, S.L. A pigmented lesion on the earlobe. Clin. Exp. Dermatol. 2015, 40, 457-459. [CrossRef]

139. Arunkajohnsak, S.; Thanomkitti, K.; Kasemsarn, P.; Pattanaprichakul, P.; Jiamton, S.; Eimpunth, S. Successful treatment of acupuncture-induced argyria using Q-switched 1064-nm Nd:YAG laser. JAAD Case Rep. 2020, 6, 984-987. [CrossRef]

140. Tanita, Y.; Kato, T.; Hanada, K.; Tagami, H. Blue macules of localized argyria caused by implanted acupuncture needles. Electron microscopy and roentgenographic microanalysis of deposited metal. Arch. Dermatol. 1985, 121, 1550-1552. [CrossRef] [PubMed]

141. Lee, S.M.; Lee, S.H. Generalized argyria after habitual use of $\mathrm{AgNO}_{3}$. J. Dermatol. 1994, 21, 50-53. [CrossRef]

142. Saager, R.B.; Hassan, K.M.; Kondru, C.; Durkin, A.J.; Kelly, K.M. Quantitative near infrared spectroscopic analysis of Q-Switched Nd:YAG treatment of generalized argyria. Lasers Surg. Med. 2013, 45, 15-21. [CrossRef]

143. Pinto-Almeida, T.; Lobo, I.; Selores, M. Unknown: Bluish-gray macules on the hands of a healthy 34 year old man. Dermatol. Online J. 2013, 19, 18964.

144. Sakai, N.; Aoki, M.; Miyazawa, S.; Akita, M.; Takezaki, S.; Kawana, S. A case of generalized argyria caused by the use of silver protein as a disinfection medicine. Acta Derm. Venereol. 2007, 87, 186-187. [CrossRef]

145. Devins, K.M.; Mogavero, H.S., Jr.; Helm, T.N. Localized argyria with pseudo-ochronosis. Cutis 2015, 95, 29-31. [PubMed]

146. Landas, S.; Bonsib, S.M.; Ellerbroek, R.; Fischer, J. Argyria: Microanalytic-morphologic correlation using paraffin-embedded tissue. Ultrastruct. Pathol. 1986, 10, 129-135. [CrossRef] [PubMed]

147. Greene, R.M.; Su, W.P. Argyria. Am. Fam. Physician 1987, 36, 151-154.

148. González-Serva, A. Normal nail anatomy, normal nail histology, and common reaction patterns. In Scher and Daniel's Nails: Diagnosis, Surgery, Therapy, 4th ed.; Rubin, A.I., Jellinek, N.J., Daniel, C.R., Scher, R.K., Eds.; Springer: Cham, Switzerland, 2018.

149. Dudeja, L.; Dudeja, I.; Janakiraman, A.; Babu, M. Ocular argyrosis: A case with silver deposits in cornea and lens. Indian J. Ophthalmol. 2019, 67, 267-268. [CrossRef]

150. Panigrahi, A.K.; Aruljothi, L.; Prajna, V.N. Argyrosis. Ophthalmology 2017, 124, 1270. [CrossRef]

151. Geyer, O.; Rothkoff, L.; Lazar, M. Clearing of corneal argyrosis by YAG laser. Br. J. Ophthalmol. 1989, 73, 1009-1010. [CrossRef]

152. Zografos, L.; Uffer, S.; Chamot, L. Unilateral conjunctival-corneal argyrosis simulating conjunctival melanoma. Arch. Ophthalmol. 2003, 121, 1483-1487. [CrossRef]

153. Yanoff, M.; Scheie, H.G. Argyrosis of the conjunctiva and lacrimal sac. Arch. Ophthalmol. 1964, 72, 57-58. [CrossRef] [PubMed]

154. Loeffler, K.U.; Lee, W.R. Argyrosis of the lacrimal sac. Graefe's Arch. Clin. Exp. Ophthalmol. 1987, 225, 146-150. [CrossRef] [PubMed]

155. Calmettes; Deodati; Amalric. Argyrosis of the crystalline lens. Bull. Soc. Ophtalmol. Fr. 1957, 7-8, 534-535.

156. Stafeeva, K.; Erlanger, M.; Velez-Montoya, R.; Olson, J.L. Ocular argyrosis secondary to long-term ingestion of silver nitrate salts. Clin. Ophthalmol. (Auckl. N. Z.) 2012, 6, 2033-2036. [CrossRef]

157. Sarnat-Kucharczyk, M.; Pojda-Wilczek, D.; Mrukwa-Kominek, E. Diagnostic methods in ocular argyrosis: Case report. Doc. Ophthalmol. 2016, 133, 129-138. [CrossRef] [PubMed] 
158. Rahimy, E.; Beardsley, R.; Ferrucci, S.; Ilsen, P.; Sarraf, D. Optical coherence tomography findings in ocular argyrosis. Ophthalmic Surg. Lasers Imaging Retin. 2013, 44, E20-E22. [CrossRef]

159. Kamath, Y.; Sinha, A. Ocular argyrosis in a jeweller. BMJ Case Rep. 2013, 2013. [CrossRef]

160. Bartley, G.B.; Buller, C.R.; Campbell, R.J.; Bullock, J.D. Pigmented episcleral mass from argyrosis following strabismus surgery. Arch. Ophthalmol. 1991, 109, 775-776. [CrossRef]

161. Frei, J.; Schröder, B.; Messerli, J.; Probst, A.; Meyer, P. Localized argyrosis 58 years after strabismus operation-An ophthalmological rarity. Klin. Mon. Augenheilkd. 2001, 218, 61-63. [CrossRef]

162. Moss, A.P.; Sugar, A.; Hargett, N.A.; Atkin, A.; Wolkstein, M.; Rosenman, K.D. The ocular manifestations and functional effects of occupational argyrosis. Arch. Ophthalmol. 1979, 97, 906-908. [CrossRef] [PubMed]

163. Sánchez-Huerta, V.; De Wit-Carter, G.; Hernández-Quintela, E.; Naranjo-Tackman, R. Occupational corneal argyrosis in art silver solderers. Cornea 2003, 22, 604-611. [CrossRef]

164. McClain, C.M.; Kantrow, S.M.; Abraham, J.L.; Price, J.; Parker, E.R.; Robbins, J.B. Localized cutaneous argyria: Two case reports and clinicopathologic review. Am. J. Dermatopathol. 2013, 35, e115-e118. [CrossRef]

165. Sugden, P.; Azad, S.; Erdmann, M. Argyria caused by an earring. Br. J. Plast. Surg. 2001, 54, 252-253. [CrossRef] [PubMed]

166. Pardo-Peret, P.; Sans-Sabrafen, J.; Boleda Relats, M. Argyriasis. Report of a case (author's transl). Med. Clin. (Barc.) 1979, 73, 386-388. [PubMed]

167. Weber, F.P.; Norman, R.H. Argyria. Proc. R. Soc. Med. 1910, 3, 75-76.

168. Davis, H. Two Cases of Pigmentation: (1) Argyria; (2) Pigmentation of Unknown Origin. Proc. R. Soc. Med. 1926, 20, 92. [CrossRef] [PubMed]

169. Smith, M.D.; Watson, W.C. Argyria: Report of two cases. Glasg. Med. J. 1954, 35, 25-26.

170. Kamalova, S.I.; Khamidullin, Z.G. Argyria as a result of the treatment of stomach ulcers with silver nitrate. Kazan Med. J. 1963, 3, 68-69.

171. Eturska, M.; Obreshkova, E. Argyria in the prolonged use of adsorgan. Vutreshni Boles. 1979, 18, 121-123.

172. Starzyńska, T.; Mandat, A. A case of argyria after peroral treatment of peptic ulcer with silver albuminate. Wiad. Lek. 1987, 40, 691-693. [PubMed]

173. Mittag, H.; Knecht, J.; Arnold, R.; Hüttich, C.; Rupec, M. Argyria. A clinical, chemical analytic and micromorphologic study. Hautarzt 1987, 38, 670-677. [PubMed]

174. Müller, M.; Wiedmann, K.H. Generalized argyria caused by targesin-containing drug used for stomach complaints. Med. Klin. (Munich) 1991, 86, 432-434. [PubMed]

175. Harrison, G.A. Section of skin from case of pigmentation (argyria). Proc. R. Soc. Med. 1924, 17, 5. [CrossRef] [PubMed]

176. Adamson, H.G. Case of Trade Argyria. Proc. R. Soc. Med. 1924, 17, 8. [CrossRef]

177. Bristol Medico Chirurgical Society. Argyria from the use of nasal drops. Bristol Med. Chir. J. (1883) 1952, 69, 143-144.

178. Smith, S.Z.; Scheen, S.R.; Allen, J.D., Jr.; Arnn, E.T. Argyria. Arch. Dermatol. 1981, 117, 595-596. [CrossRef]

179. Ondrasik, R.M.; Jordan, P.; Sriharan, A. A clinical mimicker of melanoma with distinctive histopathology: Topical silver nitrate exposure. J. Cutan. Pathol. 2020, 47, 1205-1210. [CrossRef]

180. Wan, A.T.; Conyers, R.A.; Coombs, C.J.; Masterton, J.P. Determination of silver in blood, urine, and tissues of volunteers and burn patients. Clin. Chem. 1991, 37, 1683-1687. [CrossRef]

181. Chaby, G.; Viseux, V.; Poulain, J.F.; De Cagny, B.; Denoeux, J.P.; Lok, C. Topical silver sulfadiazine-induced acute renal failure. Ann. Dermatol. Venereol. 2005, 132, 891-893. [CrossRef]

182. Trop, M.; Novak, M.; Rodl, S.; Hellbom, B.; Kroell, W.; Goessler, W. Silver-coated dressing acticoat caused raised liver enzymes and argyria-like symptoms in burn patient. J. Trauma 2006, 60, 648-652. [CrossRef] [PubMed]

183. Payne, C.M.; Bladin, C.; Colchester, A.C.; Bland, J.; Lapworth, R.; Lane, D. Argyria from excessive use of topical silver sulphadiazine. Lancet 1992, 340, 126. [CrossRef]

184. Maitre, S.; Jaber, K.; Perrot, J.L.; Guy, C.; Cambazard, F. Increased serum and urinary levels of silver during treatment with topical silver sulfadiazine. Ann. Dermatol. Venereol. 2002, 129, 217-219.

185. Silver, S. Bacterial silver resistance: Molecular biology and uses and misuses of silver compounds. FEMS Microbiol. Rev. 2003, 27, 341-353. [CrossRef]

186. Sataline, L. Tarnished silver. Lancet 2004, 363, 1166. [CrossRef]

187. Utikal, J.; Thoelke, A.; Becker, J.C.; Figl, R.; Goerdt, S.; Schadendorf, D.; Ugurel, S. Local cutaneous argyria mimicking melanoma metastases in a patient with disseminated melanoma. J. Am. Acad. Dermatol. 2006, 55, S92-S94. [CrossRef]

188. Holck, D.E.; Klintworth, G.K.; Dutton, J.J.; Foulks, G.N.; Manning, F.J. Localized conjunctival argyrosis: A late sequela of strabismus surgery. Ophthalmic Surg. Lasers 2000, 31, 495-498. [CrossRef]

189. Marner, E. Case of severe argyria after eye treatment with argyrol. Ugeskr. Laeger 1953, 115, 1061-1062.

190. Nielsen, I.O.; Kjaerbo, E. Generalized argyria due to the use of eyedrops containing silver nitrate. Ugeskr. Laeger 1989, 151, 33-34.

191. Capoen, S.C.; Boullie, M.C.; Mallet, E. Argyria in children. Arch. Fr. Pediatr. 1989, 46, 49-50.

192. Jurecka, W. Generalized argyrosis. Hautarzt 1986, 37, 628-631. [PubMed]

193. Konecný, L.; Skerík, P.; Pitha, J. General argyrosis following esophagitis therapy. Ceskoslovenska Otolaryngol. 1966, 15, 101-104.

194. Marie, J.; Léveque, B.; Watchi, J.M.; Desbois, J.C.; Feingold, J. Argyria in a child following pharyngeal sprays of silver salts repeated for 6 years. Ann. Pediatr. (Paris) 1966, 13, 2657-2659. 
195. Ohbo, Y.; Fukuzako, H.; Takeuchi, K.; Takigawa, M. Argyria and convulsive seizures caused by ingestion of silver in a patient with schizophrenia. Psychiatry Clin. Neurosci. 1996, 50, 89-90. [CrossRef]

196. Shelton, D.; Goulding, R. Silver poisoning associated with an antismoking lozenge. Br. Med. J. 1979, 1, 267. [CrossRef]

197. Macintire, D.; McLay, A.L.; East, B.W.; Williams, E.D.; Boddy, K. Silver poisoning associated with an antismoking lozenge. Br. Med. J. 1978, 2, 1749-1750. [CrossRef]

198. Van Garsse, L.; Versieck, J. General argyria caused by administration of tobacco-withdrawal tablets containing silver acetate. Ned. Tijdschr. Geneeskd. 1995, 139, 2658-2661.

199. Hau, S.C.; Tuft, S.J. Presumed corneal argyrosis from occlusive soft contact lenses: A case report. Cornea 2009, $28,703-705$. [CrossRef]

200. Bouts, B.A. Images in clinical medicine. Argyria. N. Engl. J. Med. 1999, 340, 1554. [CrossRef]

201. Fisher, R.L.; Zukerman, M. Argyrosis following prolonged intranasal medication with argyrol. J. Mich. State Med. Soc. 1948, 47, 1229. [PubMed]

202. Voldrich, Z.; Holub, M.; Plhoñ, F. Isolated case of general argyrosis after long-term administration of targesine nasal drops. Ceskoslovenska Otolaryngol. 1975, 24, 374-376.

203. Harman, R.R. Argyria. Br. J. Dermatol. 1977, 97 (Suppl. S15), 60. [CrossRef]

204. Akimov, V.N. Argyria caused by uncontrolled use of silver protein in vasomotor rhinitis. Vestnik Otorinolaringol. 1980, 6, 77-78.

205. Raimondo, L.; Garzaro, M.; Molinaro, L.; Bartoli, C.; Provenzano, E.; Pecorari, G. Iatrogenic rhinopharyngeal isolated argyria induced by silver-containing nasal drug. J. Craniofacial Surg. 2014, 25, e149-e151. [CrossRef] [PubMed]

206. Rusch-Behrend, G.D.; Gutmann, J.L. Management of diffuse tissue argyria subsequent to endodontic therapy: Report of a case. Quintessence Int. 1995, 26, 553-557. [PubMed]

207. Kissel, S.O.; Hanratty, J.J. Periodontal treatment of an amalgam tattoo. Compend. Contin. Educ. Dent. 2002, $23,930-932$.

208. D'Haeseleire, P.; Thielens, P.; Bourgois, F.; Vanclooster, R. Are Ag-points, gutta percha and amalgam still applicable for apical sealing? Acta Stomatol. Belg. 1989, 86, 243-250.

209. Schmalz, G.; Garhammer, P. Biological interactions of dental cast alloys with oral tissues. Dent. Mater. 2002, 18, 396-406. [CrossRef]

210. Shimamoto, Y.; Shimamoto, H. Systemic argyria secondary to breath freshener "Jintan Silver Pills". Hiroshima J. Med. Sci. 1987, 36, 245-247.

211. Thompson, R.; Elliott, V.; Mondry, A. Argyria: Permanent skin discoloration following protracted colloid silver ingestion. BMJ Case Rep. 2009, 2009. [CrossRef] [PubMed]

212. Chung, I.S.; Lee, M.Y.; Shin, D.H.; Jung, H.R. Three systemic argyria cases after ingestion of colloidal silver solution. Int. J. Dermatol. 2010, 49, 1175-1177. [CrossRef] [PubMed]

213. Krejci-Manwaring, J.; West, D.A.; Aires, D.J. What is your diagnosis? Argyria. Cutis 2013, 91, $233-234$.

214. Chhabra, L.; Sareen, P.; Trivedi, N. The silver man: A rare cosmetic complication of alternative medicine. BMJ Case Rep. 2013, 2013. [CrossRef] [PubMed]

215. Gorayski, P.; Pinkham, M.B.; Muir, J.B.; Pullar, A.P. Severe acute radiation dermatitis in a patient with argyria. Case Rep. Oncol. Med. 2014, 2014, 154349. [CrossRef]

216. DiGiorgio, C.M.; Wu, D.C.; Goldman, M.P. Successful treatment of argyria using the Picosecond Alexandrite Laser. Dermatol. Surg. 2016, 42, 431-433. [CrossRef] [PubMed]

217. Jung, I.; Joo, E.J.; Suh, B.S.; Ham, C.B.; Han, J.M.; Kim, Y.G.; Yeom, J.S.; Choi, J.Y.; Park, J.H. A case of generalized argyria presenting with muscle weakness. Ann. Occup. Environ. Med. 2017, 29, 45. [CrossRef]

218. Claessens, D.; Zeitz, P.F.; Beckers, H. Bluish-gray discoloration of skin and conjunctiva. Ophthalmologe 2020, 117, 66-68. [CrossRef] [PubMed]

219. Weiss, E.; Streight, K.L.; Rizk, C.B.; Markus, R. Side-by-side comparison of a Picosecond 755-nm Alexandrite Laser and a Quality-switched 1064-nm Neodymium-doped Yttrium Aluminum Garnet Laser in the treatment of argyria. Cureus 2019, 11, e5206. [CrossRef]

220. Shao, E.X.; Collins, A.; McCallum, N.; Lim, D. Electron nicroscopy of argyria treated with Picosecond Alexandrite Laser. Dermatol. Surg. 2020, 46, 1246-1249. [CrossRef]

221. Simon, M.; Buchanan, J.A. Argyria, an unexpected case of skin discoloration from colloidal silver salt ingestion. J. Emerg. Med. 2020, 59, e39-e41. [CrossRef]

222. Seitz, I.P.; Kowarik, M.C.; Sartor-Pfeiffer, J.; Ziemann, U.; Wilhelm, H.; Bartz-Schmidt, K.U. Occurrence of primary progressive multiple sclerosis in a patient with argyria: Causality or coincidence? Mult. Scler. Relat. Disord. 2020, 46, 102465. [CrossRef]

223. Han, T.Y.; Chang, H.S.; Lee, H.K.; Son, S.J. Successful treatment of argyria using a low-fluence Q-switched 1064-nm Nd:YAG laser. Int. J. Dermatol. 2011, 50, 751-753. [CrossRef] [PubMed]

224. Anderson, E.L.; Janofsky, J.; Jayaram, G. Argyria as a result of somatic delusions. Am. J. Psychiatry 2008, 165, 649-650. [CrossRef] [PubMed]

225. Okan, D.; Woo, K.; Sibbald, R.G. So what if you are blue? Oral colloidal silver and argyria are out: Safe dressings are in. Adv. Ski. Wound Care 2007, 20, 326-330. [CrossRef] [PubMed]

226. Hori, K.; Martin, T.G.; Rainey, P.; Robertson, W.O. Believe it or not-Silver still poisons! Vet. Hum. Toxicol. 2002, 44, 291-292. [PubMed] 
227. Tran, H.A.; Song, S. Silver toxicity masquerading as hypocaeruloplasminaemia. Pathology 2007, 39, 456-458. [CrossRef]

228. Baker, C.D.; Federico, M.J.; Accurso, F.J. Case report: Skin discoloration following administration of colloidal silver in cystic fibrosis. Curr. Opin. Pediatr. 2007, 19, 733-735. [CrossRef]

229. Hristov, A.C.; High, W.A.; Golitz, L.E. Localized cutaneous argyria. J. Am. Acad. Dermatol. 2011, 65, 660-661. [CrossRef]

230. Glehr, M.; Leithner, A.; Friesenbichler, J.; Goessler, W.; Avian, A.; Andreou, D.; Maurer-Ertl, W.; Windhager, R.; Tunn, P.U. Argyria following the use of silver-coated megaprostheses: No association between the development of local argyria and elevated silver levels. Bone Jt. J. 2013, 95-B, 988-992. [CrossRef]

231. Naqvi, A.H.; Shields, J.W.; Abraham, J.L. Nasal argyria (deposition of silver-selenium) in the photographic film industry: Histopathology and microanalysis. Am. J. Otolaryngol. 2007, 28, 430-432. [CrossRef]

232. Flögel, W.; Widmeier, S.; Hotz, P.; Schärer, L.; Barthelmes, D.; Landau, K.; Thiel, M.A. Corneal and conjunctival findings in systemic silver intoxication. Klin. Mon. Augenheilkd. 2006, 223, 390-392. [CrossRef] [PubMed]

233. Tajirian, A.L.; Campbell, R.M.; Robinson-Bostom, L. Localized argyria after exposure to aerosolized solder. Cutis 2006, 78, 305-308.

234. Cho, E.A.; Lee, W.S.; Kim, K.M.; Kim, S.Y. Occupational generalized argyria after exposure to aerosolized silver. J. Dermatol. 2008, 35, 759-760. [CrossRef]

235. Gallardo, M.J.; Randleman, J.B.; Price, K.M.; Johnson, D.A.; Acosta, S.; Grossniklaus, H.E.; Stulting, R.D. Ocular argyrosis after long-term self-application of eyelash tint. Am. J. Ophthalmol. 2006, 141, 198-200. [CrossRef]

236. Sakai, T.; Yamada, N.; Yamamoto, O.; Saito-Shono, T.; Yamate, T.; Ishikawa, K.; Goto, M.; Hatano, Y.; Hongo, N.; Kodera, T.; et al. Argyria due to embedded acupuncture needles and their transcaval migration into the right ventricle without serious complications. Eur. J. Dermatol. 2017, 27, 655-656. [CrossRef] [PubMed]

237. Suzuki, H.; Baba, S.; Uchigasaki, S.; Murase, M. Localized argyria with chrysiasis caused by implanted acupuncture needles. Distribution and chemical forms of silver and gold in cutaneous tissue by electron microscopy and X-ray microanalysis. J. Am. Acad. Dermatol. 1993, 29, 833-837. [CrossRef]

238. Legat, F.J.; Goessler, W.; Schlagenhaufen, C.; Soyer, H.P. Argyria after short-contact acupuncture. Lancet 1998, 352, 241. [CrossRef]

239. Takeishi, E.; Hirose, R.; Hamasaki, Y.; Katayama, I. Localized argyria 20-years after embedding of acupuncture needles. Eur. J. Dermatol. 2002, 12, 609-611.

240. Rackoff, E.M.; Benbenisty, K.M.; Maize, J.C.; Maize, J.C., Jr. Localized cutaneous argyria from an acupuncture needle clinically concerning for metastatic melanoma. Cutis 2007, 80, 423-426.

241. Alés-Fernández, M.; Ríos-Martín, J.J.; Camacho-Martínez, F.M. Localized argyria secondary to acupuncture mimicking blue nevus. J. Drugs Dermatol. 2010, 9, 1019-1020.

242. van den Nieuwenhuijsen, I.J.; Calame, J.J.; Bruynzeel, D.P. Localized argyria caused by silver earrings. Dermatologica 1988, 177, 189-191. [CrossRef] [PubMed]

243. Morton, C.A.; Fallowfield, M.; Kemmett, D. Localized argyria caused by silver earrings. Br. J. Dermatol. 1996, 135, 484-485. [CrossRef]

244. Newman, M.; Kolecki, P. Argyria in the ED. Am. J. Emerg. Med. 2001, 19, 525-526. [CrossRef] [PubMed]

245. Timmins, A.C.; Morgan, G.A. Argyria or cyanosis. Anaesthesia 1988, 43, 755-756. [CrossRef]

246. Fred, H.L. Case in point. Generalized argyria. Hosp. Pract. 1994, 29, 14. [CrossRef] [PubMed]

247. Faergemann, J. Medical history. Lancet 2002, 360, 689. [CrossRef]

248. Baernstein, A.; Smith, K.M.; Elmore, J.G. Singing the blues: Is it really cyanosis? Respir. Care 2008, 53, 1081-1084.

249. Fernandez-Flores, A.; Nguyen, T.; Cassarino, D.S. Mucocutaneous Hyperpigmentation in a Patient With a History of Both Minocycline and Silver Ingestion. Am. J. Dermatopathol. 2017, 39, 916-919. [CrossRef]

250. Hays, G.B.; Lyle, C.B., Jr.; Wheeler, C.E., Jr. Slate-Gray Color in Patients Receiving Chlorpromazine. Arch. Dermatol. 1964, 90, 471-476. [CrossRef]

251. Trimble, J.W.; Mendelson, D.S.; Fetter, B.F.; Ingram, P.; Gallagher, J.J.; Shelburne, J.D. Cutaneous pigmentation secondary to amiodarone therapy. Arch. Dermatol. 1983, 119, 914-918. [CrossRef] [PubMed]

252. Rhee, D.Y.; Chang, S.E.; Lee, M.W.; Choi, J.H.; Moon, K.C.; Koh, J.K. Treatment of argyria after colloidal silver ingestion using Q-switched 1064-nm Nd:YAG laser. Dermatol. Surg. 2008, 34, 1427-1430. [CrossRef]

253. Parker, W.A. Argyria and cyanotic heart disease. Am. J. Hosp. Pharm. 1977, 34, 287-289. [CrossRef]

254. Kejda, J.; Horák, O.; Janecková, R. Argyria imitating cardiopulmonary cyanosis (author's transl). Ceskoslovenska Dermatol. 1980, 55, 330-333.

255. Donnard, G.; Sallaberry, M.; Morand, J.J. Argyria and anesthesia. Ann. Fr. Anesth. Reanim. 1996, 15, 226. [CrossRef]

256. Travis, C. Differential diagnosis cyanosis versus argyria: When your patient remains blue-A 48-year-old trauma patient with persistent cyanosis. J. Emerg. Nurs. 2010, 36, 466-467. [CrossRef]

257. Jänner, M.; Marschelke, I.; Voigt, H. Localized intramural silver impregnation of the tongue. Differential diagnosis from malignant melanoma. Hautarzt 1980, 31, 510-512. [PubMed]

258. Landas, S.K.; Mitros, F.A.; Furst, D.E.; LaBrecque, D.R. Lipogranulomas and gold in the liver in rheumatoid arthritis. Am. J. Surg. Pathol. 1992, 16, 171-174. [CrossRef] [PubMed]

259. Hugar, S.B.; Shulman, J.; Yanta, J.; Nine, J. Ochronosis presenting as methemoglobinemia. J. Forensic Sci. 2019, 64, 913-916. [CrossRef] 
260. Atmatzidis, D.H.; Hoegler, K.; Weiss, A.; Lambert, W.C.; Schwartz, R.A. Unsafe deposits: Overlapping cutaneous manifestations of porphyria cutanea tarda, ochronosis, hemochromatosis, and argyria. Skinmed 2019, 17, 161-170.

261. Rosenman, K.D.; Moss, A.; Kon, S. Argyria: Clinical implications of exposure to silver nitrate and silver oxide. J. Occup. Med. $1979,21,430-435$.

262. Bartlett, R.E. Generalized argyrosis with lens involvement; report of an unusual case. Am. J. Ophthalmol. 1954, $38,402-403$. [CrossRef]

263. Pifer, J.W.; Friedlander, B.R.; Kintz, R.T.; Stockdale, D.K. Absence of toxic effects in silver reclamation workers. Scand. J. Work. Environ. Health 1989, 15, 210-221. [CrossRef] [PubMed]

264. Spencer, W.H.; Garron, L.K.; Contreras, F.; Hayes, T.L.; Lai, C. Endogenous and exogenous ocular and systemic silver deposition. Trans. Ophthalmol. Soc. U. K. 1980, 100, 171-178. [PubMed]

265. Zech, P.; Colon, S.; Labeeuw, R.; Blanc-Brunat, N.; Richard, P.; Perol, M. Nephrotic syndrome with silver deposits in the glomerular basement membranes during argyria. Nouv. Press. Med. 1973, 2, 161-164.

266. Watanabe, Y.; Eguchi, A.; Kamio, M.; Yamaguchi, K.; Ohara, M.; Mochizuki, T. Case of membranous nephropathy associated with argyria. Nihon Jinzo Gakkai Shi 2005, 47, 547-551.

267. McCague, A.; Joe, V.C. A Case of Argyria and Acute Leukopenia Associated with the Use of an Antimicrobial Soft Silicone Foam Dressing. J. Burn Care Res. 2016, 37, e493-e496. [CrossRef]

268. Rezk, T.; Penton, J.; Stevenson, A.; Owen-Casey, M.; Little, M.; Cunningham, J.; Salama, A.D. Pauci Immune crescentic glomerulonephritis in a patient with T-cell lymphoma and argyria. BMC Nephrol. 2016, 17, 49. [CrossRef]

269. Parkes, A. Silver-coated dressing Acticoat. J. Trauma 2006, 61, 239-240. [CrossRef]

270. Barrie, H.J.; Harding, H.E. Argyro-siderosis of the lungs in silver finishers. Occup. Environ. Med. 1947, 4, 225-229. [CrossRef]

271. Harding, H.E. Fibrosis in the lungs of a silver finisher. Br. J. Ind. Med. 1948, 5, 70-72. [CrossRef] [PubMed]

272. Stepien, K.M.; Morris, R.; Brown, S.; Taylor, A.; Morgan, L. Unintentional silver intoxication following self-medication: An unusual case of corticobasal degeneration. Ann. Clin. Biochem. 2009, 46, 520-522. [CrossRef]

273. Stepien, K.M.; Taylor, A. Colloidal silver ingestion with copper and caeruloplasmin deficiency. Ann. Clin. Biochem. 2012, 49, 300-301. [CrossRef] [PubMed]

274. Graham, S.A.; O'Meara, J.M. The feasibility of measuring silver concentrations in vivo with X-ray fluorescence. Phys. Med. Biol. 2004, 49, N259-N266. [CrossRef]

275. Czitober, H.; Frischauf, H.; Leodolter, I. Quantitative studies in generalized argyron's using neutron activation analysis. Virchows Arch. A Pathol. Pathol. Anat. 1970, 350, 44-51. [CrossRef]

276. Johansson, E.A.; Kanerva, L.; Niemi, K.M.; Lakomaa, E.L. Generalized argyria with low ceruloplasmin and copper levels in the serum. A case report with clinical and microscopical findings and a trial of penicillamine treatment. Clin. Exp. Dermatol. 1982, 7 , 169-176. [CrossRef] [PubMed]

277. Rosenthal, T.; Ollswang, A. Failure of 2,3-dimercaptopropanol in treatment of argyria. Arch. Derm. Syphilol. 1948, 57, 743-745. [CrossRef] [PubMed]

278. Kleckner, M.S., Jr. The use of BAL in generalized argyria. Calif. Med. 1949, 70, 133. [PubMed]

279. Aaseth, J.; Halse, J.; Falch, J. Chelation of silver in argyria. Acta Pharmacol. Toxicol. (Copenh.) 1986, 59 (Suppl. S7), 471-474. [CrossRef] [PubMed]

280. Almurayshid, A.; Park, S.; Oh, S.H. Effective laser treatment options for argyria: Review of literatures. J. Cosmet. Dermatol. 2020, 19, 1877-1882. [CrossRef] [PubMed]

281. Park, S.W.; Kim, J.H.; Shin, H.T.; Lee, K.T.; Lee, J.H.; Lee, D.Y.; Lee, J.H.; Yang, J.M. An Effective Modality for Argyria Treatment: Q-Switched 1064-nm Nd:YAG Laser. Ann. Dermatol. 2013, 25, 511-512. [CrossRef] [PubMed]

282. Hovenic, W.; Golda, N. Treatment of argyria using the quality-switched 1064-nm neodymium-doped yttrium aluminum garnet laser: Efficacy and persistence of results at 1-year follow-up. Dermatol. Surg. 2012, 38, 2031-2034. [CrossRef] [PubMed]

283. Krase, J.M.; Gottesman, S.P.; Goldberg, G.N. Recurrence of Argyria Post Q-Switched Laser Treatment. Dermatol. Surg. 2017, 43, 1308-1311. [CrossRef] [PubMed]

284. Mock, J.J.; Barbic, M.; Smith, D.R.; Schultz, D.A.; Schultz, S. Shape effects in plasmon resonance of individual colloidal silver nanoparticles. J. Chem. Phys. 2002, 116, 6755-6759. [CrossRef]

285. Jańczuk, Z.; Banach, J. Local argyrosis of oral mucosa or amalgam tattoo. A problem in diagnosis and treatment. Adv. Med. Sci. 2006, 51 (Suppl. S1), 62-65. [PubMed]

286. Munger, M.A.; Radwanski, P.; Hadlock, G.C.; Stoddard, G.; Shaaban, A.; Falconer, J.; Grainger, D.W.; Deering-Rice, C.E. In vivo human time-exposure study of orally dosed commercial silver nanoparticles. Nanomedicine 2014, 10, 1-9. [CrossRef] [PubMed]

287. Gonzalez, C.; Rosas-Hernandez, H.; Ramirez-Lee, M.A.; Salazar-García, S.; Ali, S.F. Role of silver nanoparticles (AgNPs) on the cardiovascular system. Arch. Toxicol. 2016, 90, 493-511. [CrossRef] [PubMed]

288. Abukabda, A.B.; Stapleton, P.A.; Nurkiewicz, T.R. Metal Nanomaterial Toxicity Variations Within the Vascular System. Curr. Environ. Health Rep. 2016, 3, 379-391. [CrossRef]

289. Teran, C.G.; Sura, S.; Cabandugama, P.; Berson, C. Silver nitrate ingestion: Report of a case with an uneventful course and review of the literature. Clin. Pract. 2011, 1, e43. [CrossRef] [PubMed]

290. Shoults-Wilson, W.A.; Reinsch, B.C.; Tsyusko, O.V.; Bertsch, P.M.; Lowry, G.V.; Unrine, J.M. Effect of silver nanoparticle surface coating on bioaccumulation and reproductive toxicity in earthworms (Eisenia fetida). Nanotoxicology 2011, 5, 432-444. [CrossRef] 